\title{
Carbon emissions from land use and land-cover change
}

\author{
R. A. Houghton ${ }^{1}$, J. I. House ${ }^{2}$, J. Pongratz ${ }^{3, *}$, G. R. van der Werf $^{4}$, R. S. DeFries ${ }^{5}$, M. C. Hansen ${ }^{6}$, C. Le Quéré7 , and $^{2}$ \\ N. Ramankutty ${ }^{8}$ \\ ${ }^{1}$ Woods Hole Research Center, Falmouth, MA, USA \\ ${ }^{2}$ Department of Geography, Cabot Institute, University of Bristol, Bristol, UK \\ ${ }^{3}$ Department of Global Ecology, Carnegie Institution for Science, Stanford, USA \\ ${ }^{4}$ Faculty of Earth and Life Sciences, VU University, Amsterdam, The Netherlands \\ ${ }^{5}$ Ecology, Evolution, and Environmental Biology, Columbia University, New York, USA \\ ${ }^{6}$ Department of Geographical Sciences, University of Maryland, College Park, USA \\ ${ }^{7}$ Tyndall Centre for Climate Change Research, University of East Anglia, Norwich, UK \\ ${ }^{8}$ Department of Geography, McGill University, Montreal, Canada \\ *now at: Max Planck Institute for Meteorology, Hamburg, Germany
}

Correspondence to: R. A. Houghton (rhoughton@whrc.org)

Received: 12 December 2011 - Published in Biogeosciences Discuss.: 19 January 2012

Revised: 10 May 2012 - Accepted: 18 November 2012 - Published: 13 December 2012

\begin{abstract}
The net flux of carbon from land use and landcover change (LULCC) accounted for $12.5 \%$ of anthropogenic carbon emissions from 1990 to 2010 . This net flux is the most uncertain term in the global carbon budget, not only because of uncertainties in rates of deforestation and forestation, but also because of uncertainties in the carbon density of the lands actually undergoing change. Furthermore, there are differences in approaches used to determine the flux that introduce variability into estimates in ways that are difficult to evaluate, and not all analyses consider the same types of management activities. Thirteen recent estimates of net carbon emissions from LULCC are summarized here. In addition to deforestation, all analyses considered changes in the area of agricultural lands (croplands and pastures). Some considered, also, forest management (wood harvest, shifting cultivation). None included emissions from the degradation of tropical peatlands. Means and standard deviations across the thirteen model estimates of annual emissions for the 1980s and 1990s, respectively, are $1.14 \pm 0.23$ and $1.12 \pm 0.25 \mathrm{Pg} \mathrm{C} \mathrm{yr}^{-1}\left(1 \mathrm{Pg}=10^{15} \mathrm{~g}\right.$ carbon). Four studies also considered the period 2000-2009, and the mean and standard deviations across these four for the three decades are $1.14 \pm 0.39,1.17 \pm 0.32$, and $1.10 \pm 0.11 \mathrm{Pg} \mathrm{Cyr}^{-1}$. For the period 1990-2009 the mean global emissions from LULCC are $1.14 \pm 0.18 \mathrm{PgC}^{-1}$. The standard deviations across model means shown here are smaller than previous estimates
\end{abstract}

of uncertainty as they do not account for the errors that result from data uncertainty and from an incomplete understanding of all the processes affecting the net flux of carbon from LULCC. Although these errors have not been systematically evaluated, based on partial analyses available in the literature and expert opinion, they are estimated to be on the order of $\pm 0.5 \mathrm{PgC} \mathrm{yr}^{-1}$.

\section{Definitions and context}

The sources and sinks of carbon from land use and landcover change (LULCC) are significant in the global carbon budget. The contribution of LULCC to anthropogenic carbon emissions were about $33 \%$ of total emissions over the last $150 \mathrm{yr}$ (Houghton, 1999), $20 \%$ of total emissions in the 1980s and 1990s (Denman et al., 2007), and $12.5 \%$ of total emissions over 2000 to 2009 (Friedlingstein et al., 2010). The declining fraction is largely the result of the rise in fossil fuel emissions. The net flux of carbon from LULCC is also the most uncertain term in the carbon budget, accounting for emissions of 1.4 (range: 0.4 to 2.3 ) $\mathrm{Pg} \mathrm{C} \mathrm{yr}^{-1}$ in the $1980 \mathrm{~s}$; 1.6 (0.5 to 2.7) $\mathrm{Pg} \mathrm{C} \mathrm{yr}^{-1}$ in the 1990s (Denman et al., 2007); and $1.1 \pm 0.7 \mathrm{Pg} \mathrm{C} \mathrm{yr}^{-1}$ from 2000 to 2009 (Friedlingstein et al., 2010). 
Several different models, data sets and methods have been applied to calculate the global net flux of carbon from LULCC. This paper reviews and synthesizes these estimates, providing an update and a more representative range across the current literature than is presented in either Denman et al. (2007) or Friedlingstein et al. (2010). The paper discusses reasons for differences across results, key areas of uncertainty in estimates, including sources of data and differences in approach, and open questions that lead to priorities for the next steps in constraining emissions from LULCC.

The flux of carbon from LULCC does not represent the total net flux of carbon between land and atmosphere. Unmanaged terrestrial ecosystems also contribute to changes in the land-atmosphere net flux (Phillips et al., 2008; Lewis et al., 2009; Pan et al., 2011). There are large annual exchanges of $\mathrm{CO}_{2}$ between ecosystems (plants and soils) and the atmosphere due to natural processes (photosynthesis, respiration) with substantial interannual variability related to climate variability. The land is currently a net sink despite LULCC emissions (Canadell et al., 2007; Le Quéré et al., 2009). This net sink is likely attributable to a combination of LULCC (e.g., forests growing on abandoned croplands) and the affects of environmental changes on plant growth, such as the fertilizing effects of rising concentrations of $\mathrm{CO}_{2}$ in the atmosphere and nitrogen $(\mathrm{N})$ deposition, and changes in climate, such as longer growing seasons in northern mid-latitude regions. These environmental drivers affect both managed and unmanaged lands and make attribution of carbon fluxes to LULCC difficult. LULCC, in theory, includes only those fluxes of carbon attributable to direct human activity and excludes those fluxes attributable to natural or indirect human effects. In practice, however, attribution is difficult, in part because of the interactions between direct and indirect effects. It is difficult to establish how much of the carbon accumulating in a planted forest, for example, can be attributed to management, as opposed to increasing concentrations of $\mathrm{CO}_{2}$ in the atmosphere.

In this paper the term "land use" refers to management within a land-cover type, such as forest or cropland. For example, the harvest of wood does not change the designation of the land as forest although the land may be temporarily treeless. "Land-cover change", in contrast, refers to the conversion of one cover type to another, for example, the conversion of forest to cropland. The largest emissions of carbon have been from land-cover change, particularly the conversion of forests to non-forests, or deforestation.

All of the analyses reviewed here have included changes in forest area, and most have included other changes in land cover (e.g., natural grassland to pastureland). All of the approaches consider changes in the areas of croplands and pastures (i.e., areas deforested or reforested) (Sect. 3.1) and the emissions coefficients (carbon lost or gained per hectare following a change in land cover) (Sects. 3.2 and 3.3). The approaches differ, first, in the way changes in area are identified and measured; and, second, in the way carbon stocks and changes in carbon stocks are estimated (some are modeled, others are specified from observations). Approaches also differ in their treatment of environmental change (Sect. 3.4) and the types of additional management activities considered (Sect. 4).

Ideally, land use and land-cover change would be defined broadly to include not only human-induced changes in land cover, but all forms of land management (e.g., tillage, fertilizer use, shifting cultivation, selective logging, draining of peatlands, use or exclusion of fire). The reason for this broad ideal is that the net flux of carbon attributable to management is that portion of a terrestrial carbon flux that might qualify for credits and debits under a post-Kyoto agreement. Besides the difficulty in separating management effects from natural and indirect effects $\left(\mathrm{CO}_{2}\right.$ fertilization, $\mathrm{N}$ deposition, and the effects of climate change), the ideal of including all land management activities requires more data, at higher spatial and temporal resolution, than has been practical (or possible) to assemble at the global level. Thus, most analyses of the effects of LULCC on carbon have focused on the dominant (or documentable) forms of management and, to a large extent, ignored others.

Most analyses include little if any land use (management within a cover type) despite the effects of land use on terrestrial carbon storage. Several analyses include wood harvest and shifting cultivation, but none has included cropland management. A reduction in the carbon density of forests as a result of management is defined here as "degradation". Thus, even sustainable harvests "degrade" forests because the mean carbon density of a sustainably logged forest is less than it would be if the forest were not logged.

LULCC also affects climate through emissions of chemically and radiatively active gases besides $\mathrm{CO}_{2}$. Further, LULCC affects climate through biophysical effects on surface albedo, surface roughness, and evapotranspiration (e.g., Pongratz et al., 2010). Non- $\mathrm{CO}_{2}$ gases and biophysical effects are not considered here.

\section{Synthesis of global LULCC estimates}

Recent estimates of the flux of carbon from LULCC are shown in Fig. 1 and summarized briefly in Table 1. A few of the estimates are not strictly global but include only tropical regions (DeFries et al., 2002; Achard et al., 2004). Nevertheless, these estimates for the tropics appear to fit within the range of global estimates because the net annual flux of carbon from LULCC in regions outside the tropics has been generally small compared to tropical fluxes over the last decades (Houghton, 2003). This near neutrality may be misleading, however. It does not indicate a lack of activity outside the tropics. Indeed, annual gross sources and sinks of carbon from LULCC are nearly as great in temperate and boreal regions as they are in the tropics (Richter and Houghton, 2011). Rates of wood harvest, for example, are nearly the same in 


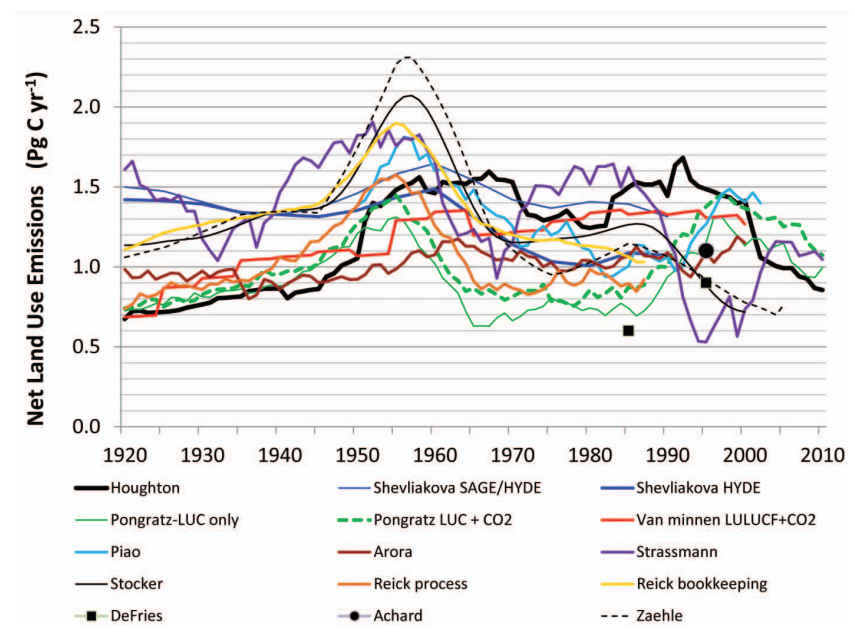

Fig. 1. Recent estimates of the net annual emissions of carbon from land use and land-cover change. The closed boxes (DeFries et al., 2002) and circle (Achard et al., 2004) represent 10-yr means for the 1980 s or 1990 s.

both regions. The main difference between the two regions is that forests are being lost in the tropics, while forest area has been expanding in Europe, China, and North America.

The mean annual net flux of carbon from LULCC based on the thirteen estimates for the 1980s and 1990s is $1.14 \pm 0.23$ and $1.12 \pm 0.25 \mathrm{PgC} \mathrm{yr}^{-1}$, respectively (mean \pm standard deviation across model means). The four estimates for 2000 2009 yield mean net sources of $1.14 \pm 0.39,1.17 \pm 0.32$, and $1.10 \pm 0.11 \mathrm{Pg} \mathrm{C} \mathrm{yr}^{-1}$ for the 1980s, 1990s, and 2000-2009, respectively. Only one of these estimates (Houghton, 2010) is based on recent estimates of deforestation rates (FAO, 2010). The three others are forced by scenarios after 2000 or 2005. For the longer interval 1990-2009 the mean net flux for all analyses is $1.14 \pm 0.18 \mathrm{Pg} \mathrm{C} \mathrm{yr}^{-1}$.

The standard deviations across model means do not reflect the larger uncertainty within each estimate due to uncertainty in data (Sect. 3) and uncertainty in understanding and accounting for multiple processes or activities (Sects. 4-5). They also do not fully represent the range around the modeled mean, which is generally in the order of $\pm 0.5 \mathrm{Pg} \mathrm{C} \mathrm{yr}^{-1}$. Thus they are smaller than the errors presented in Denman et al. (2007) and Friedlingstein et al. (2010). A fuller assessment of the uncertainty is presented in Sect. 6 following a discussion which identifies the reasons for differences among these recent estimates. Differences are grouped into several major categories: data on rates and areas of LULCC (Sect. 3.1) and data on carbon density of soils and vegetation before (Sect. 3.2) and after change (Sect. 3.3), the treatment of environmental change (e.g., $\mathrm{CO}_{2}$ and $\mathrm{N}$ fertilization, changes in temperature and moisture) (Sect. 3.4), and the types of LULCC processes included (or not) (Sects. 4-5).

\section{Interannual variability and trends}

Satellite-based observations of forest-cover loss and fires provide one estimate of the interannual variability in deforestation rates (Fig. 2). This variability may be driven by commodity prices, institutional measures, and climate conditions. Over the period 2001-2004 clearing rates in the Brazilian state of Mato Grosso were correlated with soy prices (Morton et al., 2006). Longer and more extreme dry seasons, allowing for a more effective use of fire, have been linked to higher clearing rates in Indonesia (van der Werf et al., 2008) and the Amazon (Aragão et al., 2008). In Southeast Asia the emissions during dry El Niño years may be one or even two orders of magnitude larger than emissions during wet La Niña years, and at least some of this variability in emissions results from uses of land tied to climatic variations.

Regarding a trend in global emissions from LULCC, no trend stands out in the family of curves in Fig. 1. Those analyses that extend to 2010 suggest a recent downturn in net emissions, not statistically significant but consistent with decreased rates of deforestation reported by the UN's Food and Agriculture Organization (FAO) in their 2010 Forest Resources Assessment (FRA) and with declining rates of deforestation observed in the two countries with the highest rates (Fig. 2). However, preliminary results from the FAO \& JRC (2012) remote sensing survey suggest the reverse trend: higher deforestation rates in 2000-2005 than in the 1990s. Reduced rates of deforestation in Brazil appear to have been offset by increased rates in other South American countries.

The annual net loss of forest area in the tropics, as reported in the 2010 FRA (FAO, 2010) decreased from 11.55 million ha $\mathrm{yr}^{-1}$ for $1990-2000$ to 8.62 million ha $\mathrm{yr}^{-1}$ over the period 2000-2010. In contrast, initial results from the FAO \& JRC (2012) survey show an increase in tropical net deforestation rates from $\sim 8.2$ million ha $\mathrm{yr}^{-1}$ during the 1990-2000 period to $\sim 10.0$ million, ha $\mathrm{yr}^{-1}$ during the 2000-2005 period. At this point it is unclear which estimate of deforestation is more accurate. Are the country-based estimates of the FRA subject to large errors (Grainger, 2008), or is the regularly spaced sample covering $1 \%$ of tropical forests insufficient to capture the aggregated nature of deforestation rates (Steininger et al., 2009)? Over the longer period 1990 to 2005 , the means of the two estimates are within $\sim 10 \%$ of each other.

\section{Approaches and data}

\subsection{Changes in area}

Three approaches have been used to document changes in the area of ecosystems or changes in land cover: nationally aggregated land-use statistics, satellite data on land cover, and satellite data on fires. 
Table 1. Key characteristics of the data sets shown in Fig. 1. Note that several studies provide a range of different estimates of land-use emissions; the datasets shown in this study were chosen as the ones closest to a bookkeeping approach or to isolate certain processes.

\begin{tabular}{|c|c|c|c|c|c|c|c|c|c|}
\hline $\begin{array}{l}\text { Study } \\
\text { (Fig. 1) }\end{array}$ & Reference & Approach & LULCC types & LULCC source & Carbon fluxes & $\begin{array}{l}\text { Beginning } \\
\text { of accoun- } \\
\text { ting }(A D)^{1}\end{array}$ & Spatial detail $^{2}$ & $\begin{array}{l}\text { Emissions } \\
1920 \text { to } \\
1999 \\
\left(\mathrm{Pg} \mathrm{C}_{\mathrm{yr}}{ }^{-1}\right)\end{array}$ & $\begin{array}{l}\text { Emissions } \\
1990 \text { to } \\
1999 \\
\left(\mathrm{Pg} \mathrm{C} \mathrm{yr}^{-1}\right)\end{array}$ \\
\hline Achard & $\begin{array}{l}\text { Achard et al. } \\
(2004)\end{array}$ & $\begin{array}{l}\text { Bookkeeping } \\
\text { model }\end{array}$ & $\begin{array}{l}\text { De/reforestation, } \\
\text { forest degrada- } \\
\text { tion, peat fires }\end{array}$ & $\begin{array}{l}\text { Remote sensing, } \\
\text { FAO Remote } \\
\text { Sensing Survey }\end{array}$ & Actual direct & 1990 & $\begin{array}{l}\text { Explicit (only } \\
\text { tropics) }\end{array}$ & - & 1.10 \\
\hline Arora & $\begin{array}{l}\text { Arora and } \\
\text { Boer (2010) }\end{array}$ & $\begin{array}{l}\text { Process model } \\
(\mathrm{CTEM})\end{array}$ & Cropland & $\begin{array}{l}\text { Ramankutty and } \\
\text { Foley (1999) }\end{array}$ & Actual direct & 1850 & Explicit & 0.92 & 1.06 \\
\hline DeFries & $\begin{array}{l}\text { DeFries et } \\
\text { al. (2002) }\end{array}$ & $\begin{array}{l}\text { Bookkeeping } \\
\text { model }\end{array}$ & De/reforestation & Remote sensing & Actual direct & 1982 & $\begin{array}{l}\text { Explicit (only } \\
\text { tropics) }\end{array}$ & - & 0.90 \\
\hline Houghton & $\begin{array}{l}\text { Houghton } \\
(2010)\end{array}$ & $\begin{array}{l}\text { Bookkeeping } \\
\text { model }\end{array}$ & $\begin{array}{l}\mathrm{Ag}^{3} \text { incl. shifting } \\
\text { cultivation in } \\
\text { Latin America/ } \\
\text { tropical Asia, } \\
\text { and wood harvest }\end{array}$ & $\begin{array}{l}\text { FAO and national } \\
\text { censuses }\end{array}$ & Actual direct & 1850 & Regional & 1.21 & 1.50 \\
\hline Piao & $\begin{array}{l}\text { Piao et al. } \\
(2009)\end{array}$ & $\begin{array}{l}\text { Process model } \\
\text { (ORCHIDEE) }\end{array}$ & $\mathrm{Ag}$ & $\begin{array}{l}\text { Ramankutty and } \\
\text { Foley (1999) (crop- } \\
\text { land), HYDE2.0 } \\
\text { (pasture), IMAGE } \\
\text { (after 1992) }\end{array}$ & $\begin{array}{l}\text { Actual direct in- } \\
\text { cluding effects of } \\
\text { observed } \mathrm{CO}_{2} \text { and } \\
\text { climate change }\end{array}$ & 1900 & Explicit & 1.31 & 1.24 \\
\hline $\begin{array}{l}\text { Pongratz } \\
\text { LUC }\end{array}$ & $\begin{array}{l}\text { Pongratz et } \\
\text { al. (2009) }\end{array}$ & $\begin{array}{l}\text { Process model } \\
(\mathrm{JSBACH})\end{array}$ & $\mathrm{Ag}$ & $\begin{array}{l}\text { Pongratz et al. } \\
(2008)^{4}\end{array}$ & Actual direct & 800 & Explicit & 0.90 & 1.14 \\
\hline $\begin{array}{l}\text { Pongratz } \\
\mathrm{LUC}+\mathrm{CO}_{2}\end{array}$ & $\begin{array}{l}\text { Pongratz et } \\
\text { al. (2009) }\end{array}$ & $\begin{array}{l}\text { Process model } \\
(\mathrm{JSBACH})\end{array}$ & $\mathrm{Ag}$ & $\begin{array}{l}\text { Pongratz et al. } \\
(2008)^{3}\end{array}$ & $\begin{array}{l}\text { Actual direct in- } \\
\text { cluding effects of } \\
\text { simulated } \mathrm{CO}_{2} \text { and } \\
\text { climate change }\end{array}$ & 800 & Explicit & 0.99 & 1.30 \\
\hline $\begin{array}{l}\text { Reick } \\
\text { process }\end{array}$ & $\begin{array}{l}\text { Reick et } \\
\text { al. (2010) }\end{array}$ & $\begin{array}{l}\text { Process model } \\
\text { (JSBACH) }\end{array}$ & $\mathrm{Ag}$ & $\begin{array}{l}\text { Pongratz et al. } \\
(2008)^{4}\end{array}$ & Actual direct & 800 & Explicit & 1.03 & - \\
\hline $\begin{array}{l}\text { Reick book- } \\
\text { keeping }\end{array}$ & $\begin{array}{l}\text { Reick et } \\
\text { al. (2010) }\end{array}$ & $\begin{array}{l}\text { Bookkeeping } \\
\text { model }\end{array}$ & $\mathrm{Ag}$ & $\begin{array}{l}\text { Pongratz et al. } \\
(2008)^{4}\end{array}$ & Actual direct & 800 & Explicit & 1.34 & - \\
\hline $\begin{array}{l}\text { Shevliakova } \\
\text { HYDE/SAGE }\end{array}$ & $\begin{array}{l}\text { Shevliakova } \\
\text { et al. (2009) }\end{array}$ & $\begin{array}{l}\text { Process model } \\
\text { (LM3V) }\end{array}$ & $\begin{array}{l}\mathrm{Ag} \text { incl. shifting } \\
\text { cultivation in } \\
\text { tropics, and } \\
\text { wood harvest }\end{array}$ & Hurtt et al. $(2006)^{5}$ & Actual direct & 1700 & Explicit & 1.44 & 1.31 \\
\hline $\begin{array}{l}\text { Shevliakova } \\
\text { HYDE }\end{array}$ & $\begin{array}{l}\text { Shevliakova } \\
\text { et al. (2009) }\end{array}$ & $\begin{array}{l}\text { Process model } \\
\text { (LM3V) }\end{array}$ & $\begin{array}{l}\text { Ag incl. shifting } \\
\text { cultivation in } \\
\text { tropics, and } \\
\text { wood harvest }\end{array}$ & Hurtt et al. $(2006)^{6}$ & Actual direct & 1700 & Explicit & 1.28 & 1.07 \\
\hline Strassmann & $\begin{array}{l}\text { Strassmann } \\
\text { et al. (2008) }\end{array}$ & $\begin{array}{l}\text { Process model } \\
\text { (LPJ in BernCC) }\end{array}$ & $\mathrm{Ag}$, urban & HYDE2.0 adjusted & Actual direct & 1700 & Explicit & 1.39 & 0.75 \\
\hline Stocker & $\begin{array}{l}\text { Stocker et } \\
\text { al. (2011) }\end{array}$ & $\begin{array}{l}\text { Process model } \\
\text { (LPJ in BernCC, } \\
\text { updated since } \\
\text { Strassmann, } \\
2008 \text { ) }\end{array}$ & $\mathrm{Ag}$, urban & HYDE3.1 adjusted & Actual direct & $10000 \mathrm{BC}$ & Explicit & 1.31 & 0.93 \\
\hline Van Minnen & $\begin{array}{l}\text { Van Minnen } \\
\text { et al. (2009) }\end{array}$ & $\begin{array}{l}\text { Process model } \\
\text { (IMAGE2) }\end{array}$ & $\begin{array}{l}\mathrm{Ag} \text {, wood } \\
\text { harvest }\end{array}$ & $\begin{array}{l}\text { HYDE (ag), } \\
\text { IMAGE2 (w.h.) }\end{array}$ & $\begin{array}{l}\text { Actual direct in- } \\
\text { cluding effects of } \\
\mathrm{CO}_{2} \text {, climate } \\
\text { change, and } \\
\text { management }\end{array}$ & 1700 & & 1.16 & 1.33 \\
\hline Zaehle & $\begin{array}{l}\text { Zaehle et al. } \\
\text { (2011) }\end{array}$ & $\begin{array}{l}\text { Process model } \\
(\mathrm{O}-\mathrm{CN})\end{array}$ & $\mathrm{Ag}$, urban & Hurtt et al. (2006) & Actual direct & 1700 & & 1.32 & 0.97 \\
\hline
\end{tabular}

${ }^{1}$ I.e., legacy emissions of earlier time periods not considered.

2 Unless otherwise noted, studies considered all land area.

3 "Ag" stands for changes in land cover caused by expansion or abandonment of agricultural area; agriculture includes both cropland and pasture.

${ }^{4}$ Based on SAGE cropland and SAGE pasture with rates of pasture changes from HYDE, preferential allocation of pasture on natural grassland.

5 Based on SAGE cropland and HYDE pasture, proportional scaling of natural vegetation.

6 Based on HYDE cropland and HYDE pasture, proportional scaling of natural vegetation.

7 An "autonomous growth factor" approximates increase in plant productivity due to nitrogen fertilization and forest management changes. 


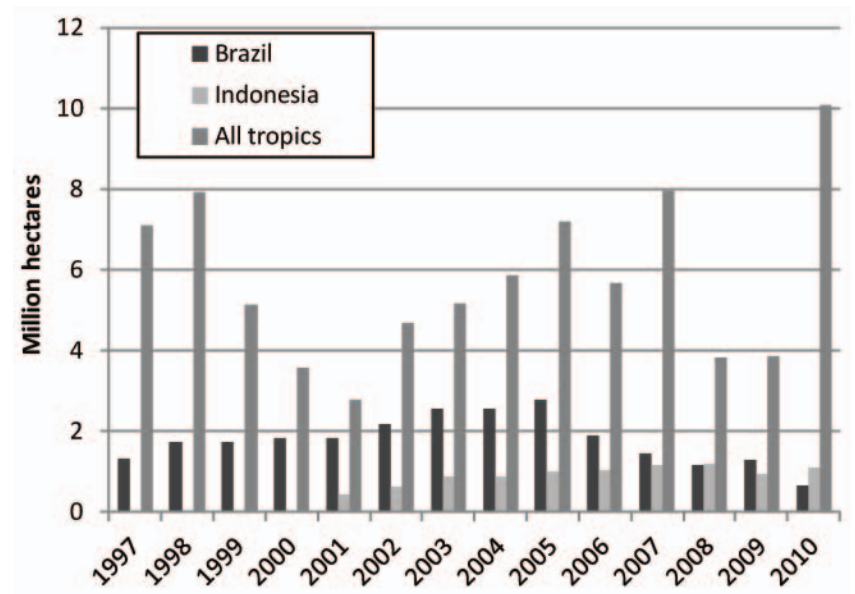

Fig. 2. Interannual variation in rates of deforestation in Brazil (dark bars) (INPE, 2010) in Indonesia (light bars) (Hansen et al., 2009 and updated) and in all tropical forests (van der Werf et al., 2010). The values for Brazil include only the loss of intact forest within the Legal Amazonia, while for Indonesia they include the loss of all forests meeting the definition of $30 \%$ cover and $5 \mathrm{~m}$-tall canopy at $60 \mathrm{~m}$ spatial resolution (approximately half of these Indonesian forests are intact). The pantropical estimates are based on burned area and active fire detections in forested areas.

\subsubsection{Nationally aggregated land-use statistics}

Historic land-use change data sets have been constructed based on aggregated, non-spatial data on LULCC, as reported in national and international statistics. The FAO provides two data sets that have been used to estimate changes in land cover over recent decades. One data set (FAOSTAT, 2009) reports annual areas in croplands and pastures from 1961. The other data set (Forest Resource Assessments, FRAs; FAO 2001, 2006, 2010) provides information on forest area and carbon stocks from 1990 to 2010 . Both data sets include nearly all countries and, hence, enable global estimates to be calculated. The data are not spatially explicit, however, and do not specify the cover type from which conversion happens. They require independent data or allocation rules to assign changes in forest or cropland area to or from particular ecosystem types (with specific carbon densities) and to particular spatial locations. The FAOSTAT data report areas of cropland and pasture annually, thus providing the basis for calculating annual rates of land-cover change. However, these changes are net changes, not gross changes. Net changes in land cover underestimate gross sources and sinks of carbon that result from simultaneous clearing for, and abandonment of, agricultural lands, for example, underestimating areas of secondary forests and their carbon sinks.

Approaches based on these FAO data assign deforested areas to either croplands or pastures, as in the Houghton data set (Houghton, 2003). This data set is not spatially explicit but aggregates country data into regional data. Spatially explicit approaches based on FAOSTAT make assump- tions about whether agricultural expansion occurs at the expense of grasslands or forests, and where these changes take place, as in the SAGE (Ramankutty and Foley, 1999) and HYDE (Klein Goldewijk, 2001) data sets. The distinctions are important because different locations have different carbon stocks, and the carbon flux resulting from LULCC depends on assumptions about both land-cover type and carbon stocks before and after change. Remote sensing-based information on recent land-cover change (see next Sect. 3.1.2) can also be combined with regional tabular statistics from FAO to reconstruct spatially explicit land-cover changes covering more than the satellite era (Ramankutty and Foley, 1999; Klein Goldewijk, 2001; Pongratz et al., 2008). The FAO data sets (FRA and FAOSTAT) have also been used in combination to estimate rates of deforestation for shifting cultivation (Houghton and Hackler, 2006), a rotational use of land with repeated clearing and subsequent regrowth of fallow forests.

The FAO data rely on reporting by individual countries. They are more accurate for some countries than for others and are not without inconsistencies and ambiguities (Grainger, 2008). Revisions in the reported rates of deforestation from one 5-yr FRA assessment to the next may be substantial due to different methods or data being used. FAO estimates of deforestation rates over the last few decades have been reduced by incorporating satellite data (FAO, 2001, 2006, 2010).

Data on historical land-area change prior to the FAO reports have been obtained from a variety of national and international historical narratives as well as population and socioeconomic data, and national land-use statistics. Agricultural expansion has been distributed spatially on the basis of population densities (Klein Goldewijk, 2001) and hindcasting of the current distribution of agricultural lands (Ramankutty and Foley, 1999). Data sets have been updated and extended to the pre-industrial past (Pongratz et al., 2008; Klein Goldewijk et al., 2011).

Two spatial data sets, in particular, have been used in most of the analyses included in Fig. 1: the SAGE data set, including cropland areas from 1700-1992 (Ramankutty and Foley, 1999), and the HYDE data set, including both cropland and pasture areas (Klein Goldewijk, 2001). The difference in using these two data sets accounts for about a $15 \%$ difference in flux estimates over the period 1850-1990 (Shevliakova et al., 2009) and 1920-1990 (Fig. 1; Table 1). Other recent data sets, such as the ones compiled by Hurtt et al. (2006) and Pongratz et al. (2008), are based on combinations of SAGE, HYDE and Houghton data sets, including updates.

\subsubsection{Satellite data on land cover}

A complementary approach for estimating LULCC is to use a time series of satellite data to estimate the spatio-temporal dynamics of change. In general, satellite data alleviate the concerns of bias, inconsistency, and subjectivity in country reporting (Grainger, 2008). Depending on the spatial and 
temporal resolution, satellite data can also distinguish between gross and net losses of forest area. However, increases in forest area are more difficult to observe with satellite data than decreases because forest growth is a more gradual process. Furthermore, although satellite data are good for measuring changes in forest area, they have generally not been used to distinguish the types of land use following deforestation (e.g., croplands, pastures, shifting cultivation). Exceptions include the regional studies by Morton et al. (2006) and Galford et al. (2008).

Satellite-based methods include both high-resolution sample-based methods and wall-to-wall mapping analyses. Sample-based approaches employ systematic or stratified random sampling to quantify gains or losses of forest area at national, regional and global scales (Achard et al., 2002, 2004; Hansen et al., 2008a, 2010). Systematic sampling provides a framework for forest area monitoring. The UN-FAO Forest Resource Assessment Remote Sensing Survey uses samples at every latitude/longitude intersection to quantify biome and global-scale forest change dynamics from 1990 to 2005 (FAO \& JRC, 2012). Other sampling approaches stratify by intensity of change, thereby reducing sample intensity. Achard et al. (2002) provided an expert-based stratification of the tropics to quantify forest cover loss from 1990 to 2000 using whole Landsat image pairs. Hansen et al. (2008a, 2010) employed MODIS data as a change indicator to stratify biomes into regions of homogeneous change for Landsat sampling.

Sampling methods such as described above provide regional estimates of forest area and change with uncertainty bounds, but they do not provide a spatially explicit map of forest extent or change. Wall-to-wall mapping does. While coarse-resolution data sets $(>4 \mathrm{~km}$ ) have been calibrated to estimate wall-to-wall changes in area (DeFries et al., 2002), recent availability of moderate spatial resolution data $(<100 \mathrm{~m})$, typically Landsat imagery $(30 \mathrm{~m})$, allows a more finely resolved approach. Historical methods rely on photointerpretation of individual images to update forest cover on annual or multi-year bases, such as with the Forest Survey of India (Global Forest Survey of India, 2008) or the Ministry of Forestry Indonesia products (Government of Indonesia/World Bank, 2000). Advances in digital image processing have led to the operational implementation of mapping annual forest-cover loss with the Brazilian PRODES (INPE, 2010) and the Australian National Carbon Accounting products (Caccetta et al., 2007). These two systems rely on cloud-free data to provide single-image/observation updates on an annual basis. Persistent cloud cover has limited the derivation of products in regions such as the Congo Basin and Insular Southeast Asia (Ju and Roy, 2008). For such areas, Landsat data can be used to generate multi-year estimates of forest-cover extent and loss (Hansen et al., 2008b; Broich et al., 2011a). For regions experiencing forest change at an agro-industrial scale, MODIS data provide a capabil- ity for integrating Landsat-scale change to annual time-steps (Broich et al., 2011b).

In general, moderate spatial resolution imagery is limited in tropical forest areas by data availability. Currently Landsat is the only source of data at moderate spatial resolution available for tropical monitoring, but to date an uneven acquisition strategy among bioclimatic regimes limits the application of generic biome-scale methods with Landsat. No other system has the combination of (1) global acquisitions, (2) historical record, (3) free and accessible data, and (4) standard terraincorrected imagery, along with robust radiometric calibration, that Landsat does. Future improvements in moderate spatial resolution tropical forest monitoring can be obtained by increasing the frequency of data acquisition.

The primary weakness of satellite data is that they are not available before the satellite era (Landsat began in 1972). Long time series are required for estimating legacy emissions of past land-use activity (Sect. 3.3). Although maps, at varying resolutions, exist for many parts of the world, spatial data on land cover and land-cover change became available at a global level only after 1972, at best. In fact, there are many gaps in the coverage of the Earth's surface before 1999 when the first global acquisition strategy for moderate spatial resolution data was undertaken with the Landsat Enhanced Thematic Mapper Plus sensor (Arvidson et al., 2001). The long-term plan of Landsat ETM+ data includes annual global acquisitions of the land surface, but cloud-cover and phenological variability limit the ability to provide annual global updates of forest extent and change. The only other satellite system that can provide global coverage of the land surface at moderate resolution is the ALOS PALSAR radar instrument, which also includes an annual acquisition strategy for the global land surface (Rosenquist et al., 2007). However, large area forest-change mapping using radar data has not yet been implemented.

\subsubsection{Satellite data on fires}

A third approach, applied so far only in tropical forests, uses satellite detection of fires in forests to estimate emissions from deforestation based on the assumption that a large proportion of land clearing in the tropics is by fire (van der Werf et al., 2010). The approach provides an estimate of gross forest loss but does not identify LULCC where fire is absent, for example, wood harvest. Nor does it distinguish between intentional deforestation fires and escaped wildfires. The approach combines estimates of burned area (Giglio et al., 2010) with complementary observations of fire occurrence (Giglio et al., 2003). It makes assumptions about how much fire is for clearing. At province or country level, clearing rates calculated this way capture up to about $80 \%$ of the variability and also $80 \%$ of the total clearing rates found by other approaches (Hansen et al., 2008a; INPE, 2010). One advantage of the fire-counting approach is that it allows for an estimate of interannual variability (see Sect. 2.1, above). 


\subsection{Carbon stocks and changes in them: data sources and modeling approaches}

Three approaches have been used to estimate carbon density $\left(\mathrm{MgCha}^{-1}\right)$ and changes in carbon density as a result of LULCC: inventory-based estimates of carbon density used with bookkeeping model approaches to tracking change in carbon pools, satellite-based estimates of carbon density used with a variety of model approaches, and process-based vegetation models that internally calculate biomass density and changes in carbon pools based on environmental drivers.

\subsubsection{Inventory-based estimates}

Inventory methods use ground-based measurements reported in forestry and agricultural statistics and the ecological literature. Inventory data are available on the carbon density of vegetation and soils in different ecosystem types, and the changes in them following disturbance or management. Extensive data are available in many temperate regions, but data are more limited in tropical regions. These data on carbon density are combined with data on changes in land cover to track changes in carbon using empirical bookkeeping models. These models track areas of change and types of change, and use standard growth and decomposition curves to track changes in carbon pools. For example, conversion of native vegetation to cropland (i.e., cultivation) causes $25-30 \%$ of the soil organic carbon in the top meter to be lost (Post and Kwon, 2000; Guo and Gifford, 2002; Murty et al., 2002). The conversion of lands to pastures, generally not cultivated, typically has less of an effect on soil carbon. This tracking approach is appropriate for non-spatial models. It assigns an average carbon density for biomass and for soils to all land within a small number of particular ecosystem types (e.g., deciduous forest, grassland). Considerable uncertainty arises because, even within the same forest type, the spatial variability in carbon density is large, in part because of variations in soils and microclimate, and in part because of past disturbances and recovery. Furthermore, literature-based estimates of carbon density are representative of a specific time and do not capture changes in carbon density that may occur from environmental effects such as natural disturbance, pollution, $\mathrm{CO}_{2}$ fertilization and climate change.

\subsubsection{Satellite-based estimates}

New satellite techniques are being applied to estimate aboveground carbon densities. Examples of mapping aboveground carbon density over large regions include work with MODIS (Houghton et al., 2007), multiple satellite data (Saatchi et al., 2007, 2011), radar (Treuhaft et al., 2009), and lidar (Baccini et al., 2012) (see Goetz et al., 2009, for a review). While the accuracy is lower than site-based inventory measurements (inventory data are generally used to calibrate satellite algorithms), the satellite data are far less intensive to collect, can cover a wide spatial area, and thus can better capture the spatial and temporal variability in aboveground carbon density. By matching carbon density to the actual area of forest being deforested, this approach has the potential to increase the accuracy of flux estimates, especially in tropical areas where variability of carbon density is high, and data availability is poor.

The capability of measuring changes in carbon density through monitoring is in its infancy, but such a capability would enable a method for estimating carbon sources and sinks that is more direct than identifying disturbance first, and then assigning a carbon density or change in carbon density (Houghton and Goetz, 2008). The approach would require models and ancillary data to calculate changes in soil, slash, and wood products. Furthermore, estimation of change, by itself, would not distinguish between deliberate LULCC activity and indirect anthropogenic or natural drivers. Nevertheless, estimation of change in aboveground carbon density has clear potential for improving calculations of sources and sinks of carbon.

\subsubsection{Modeled estimates}

Process-based ecosystem models calculate internally the carbon density of vegetation and soils in different types of ecosystems based on climate drivers and other factors within the models (see e.g., McGuire et al., 2001; Friedlingstein et al., 2006 for model intercomparisons). These models simulate spatial and temporal variations in ecosystem structure and physiology. Models differ in detail with respect to number of plant functional types (PFT's) (e.g., tropical evergreen forest, temperate deciduous forest, grassland) and number of carbon pools (e.g., fast and slow decaying fractions of soil organic matter). They simulate changes in carbon density by accounting for disturbances and recovery, whether natural or anthropogenic.

Net primary productivity is simulated in these ecosystem models as a function of the vegetation or PFT, local radiative, thermal, and hydrological conditions of the soil and the atmosphere, as well as the atmospheric composition. Soil organic matter decomposition is commonly controlled by temperature and soil moisture. The ecosystem models, therefore, respond to changes in climate and atmospheric composition. The models emphasize different aspects of ecosystem dynamics, with some accounting for competition between PFTs, nutrient limitation, and natural disturbances.

Anthropogenic land-cover change is usually prescribed from maps based on spatially explicit data sets, such as HYDE or SAGE (Sect. 3.1). The land-cover change leads to a change in the fraction of PFT that is present at that location, and a subsequent re-allocation of carbon to the atmosphere, to soil and to product pools, where carbon decomposes with different turnover rates. Models differ widely with respect to implementation of land use (management), e.g., wood harvest, grazing, and other management activities. 
Regrowth follows abandonment of managed land. In the absence of detailed information on land conversion, specific allocation rules have to be applied to determine which natural vegetation type is reduced or expanded when managed land expands or is abandoned. Common rules include a proportional reduction of natural vegetation (Pitman et al., 2009) and the preferential allocation of pasture to natural grassland (Pongratz et al., 2008).

In contrast to bookkeeping models that specify changes in soil and vegetation carbon density based on a limited number of observations, process-based models calculate vegetation and soil carbon density and changes in them for a greater number of PFT's. Furthermore, both net primary production (NPP) and decomposition vary over time in response to climate change and, if included in the model, to the fertilizing effects of changes in atmospheric $\mathrm{CO}_{2}$ and $\mathrm{N}$. The processbased models can therefore reflect much greater spatial and temporal variability in carbon density and response to environmental conditions than bookkeeping models, but their modeled carbon stocks may differ markedly from observations.

The sensitivity of carbon fluxes to the choice of model has been assessed in two studies. McGuire et al. (2001) applied four different process-based ecosystem models to similar data on cropland expansion; resulting land-cover emis-

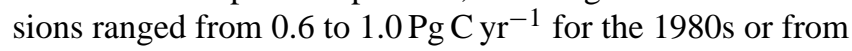
56 to $91 \mathrm{Pg} \mathrm{C}$ for 1920-1992. Reick et al. (2010) applied a process-based model (JSBACH) and a bookkeeping approach (based on Houghton, 2003) to identical LULCC data and found that land-cover emissions were $40 \%$ higher for the bookkeeping approach than the process-based approach (153 vs. $110 \mathrm{Pg}$ C for $1850-1990$ ) (see Fig. 1 and Table 1). The difference could be attributed almost entirely to differences in soil carbon changes; the bookkeeping model assumed a $25 \%$ loss of soil carbon to the atmosphere with cultivation of native soils, while the process-based model calculated soil carbon changes based on changes in NPP and the input of organic material associated with the change in land use. Differences in the way models treat environmental change is addressed in Sect. 3.4.

\subsubsection{Fires-based estimates}

When satellite-based observations of fires in tropical forests are used to estimate rates of deforestation, the associated emissions of carbon are estimated by combining the firedetermined clearing rates with modeled carbon densities (van der Werf et al., 2010). Aboveground carbon densities are modeled (as in Sect. 3.2.3, above), but the changes in carbon density as a result of fire are calculated differently from the methods described above. The fraction of aboveground biomass lost to fire is based on a pre-defined range of combustion completeness using literature values and a scaling factor based on the fire persistence. This metric captures how many times a fire is seen in the same grid cell, and is related to the completeness of conversion; multiple fire events are needed for complete removal of biomass, resulting in high fire persistence (Morton et al., 2008) and high combustion completeness (van der Werf et al., 2010).

Over the period 1997-2010, average fire emissions from deforestation and degradation in the tropics with this approach were $0.4 \mathrm{PgC}^{-1}$, with considerable uncertainty. Fires from peatlands added another $0.1 \mathrm{Pg} \mathrm{C} \mathrm{yr}^{-1}$ (Sect. 5.1), for a total of $0.5 \mathrm{PgC} \mathrm{yr}^{-1}$. This estimate does not include emissions from respiration and decay of residual plant material and soils, nor does it account for changes in land use that do not rely on fire. To account for decay, fire emissions were doubled (Barker et al., 2007; Olivier et al., 2005), yielding an annual average estimate of $\sim 1 \mathrm{PgC} \mathrm{yr}^{-1}$, in line with global model-based estimates (Fig. 1), (although none of the global model-based estimates included emissions from drained and burned peatlands). Future research is needed to determine the exact ratio between fire and decay, something that is highly variable depending on post-deforestation land use. The main advantage of using fire to study deforestation emissions is that the fire emissions can be constrained using emitted carbon monoxide, which is routinely monitored by satellites and provides a much larger departure from background conditions than emitted $\mathrm{CO}_{2}$ (e.g., van der Werf et al., 2008).

The approach underestimates carbon emissions for uses of land, such as wood harvest, that do not involve fire; it can potentially overestimate LULCC carbon emissions if it accidentally includes natural fires (i.e., part of the natural cycle of fire and regrowth not subsequently resulting in an anthropogenic LULCC). Changes in forest area as determined from satellite data are not clearly attributable to management, as opposed to natural, processes. By definition, the sources and sinks of carbon for LULCC should not include the sources and sinks from natural disturbances and recovery. The latter are part of the residual terrestrial net flux. Fires, in particular, are difficult to attribute to natural processes, indirect effects (e.g., anthropogenic climate change), or direct management. The point here is that natural disturbances and recovery may be accidentally included in satellite-based analyses of LULCC.

\subsection{The treatment of delayed (legacy) fluxes}

In addition to the areas affected annually by LULCC and the carbon densities of the lands affected, rates of decomposition and rates of recovery following LULCC vary among models. Lags in emissions and sinks of carbon are not treated consistently, adding to the differences among flux estimates. To help illustrate the effects of these components, it is helpful to distinguish the net annual flux of carbon from the gross sources and sinks that comprise it. Houghton's analysis (Fig. 1) is used as an illustration. The mean net flux of carbon from LULCC by this estimate was a global source of 1.1 $\mathrm{Pg} \mathrm{C} \mathrm{yr}^{-1}$ over the period 2000-2009. Gross sources and sinks of carbon were about three times greater (Fig. 3a and b) 
and probably underestimated because deforestation (based on FAO FRA data) was driven by net (rather than gross) changes in forest and agricultural area, thereby underestimating agricultural abandonment and the area of secondary forests.

Instantaneous emissions occur in the year of the disturbance, e.g., due to fire and rapid decomposition of carbon pools. Legacies result from the longer-term losses of carbon from dead biomass, soils, and forest products and the longerterm uptake of carbon in regrowing secondary forests. While the differences do not affect cumulative emissions over a long time period, short-term emission fluxes can vary substantially (Ramankutty et al., 2007).

The fraction and fate of biomass removed as a result of LULCC varies depending on the land use following clearing (Morton et al., 2008). Mechanized agriculture generally involves more complete removal of above- and belowground biomass than clearing for small-scale farming or pasture. For example, in the southern Amazon state of Mato Grosso, estimated average emissions for 2001-2005 were $116 \mathrm{Mg} \mathrm{Cha}^{-1}$ when forests were converted to cropland and $94 \mathrm{Mg} \mathrm{Cha}^{-1}$ when they were converted to pasture (DeFries et al., 2008). Incorporating post-clearing land cover in estimating carbon emissions from land-use change will reduce uncertainties (Galford et al., 2010).

The existence of delayed fluxes implies that estimates of current fluxes must include data on historical land-cover activities and associated information on the fate of cleared carbon. However, such historical data are not included in all analyses, especially in studies using remote-sensing data where information is available only since the 1970s at best (DeFries et al., 2002; Archard et al., 2004). This leads to the question of how far back in time one needs to conduct analyses in order to estimate current emissions accurately, or, alternatively, how much current emissions are underestimated by ignoring historical legacy fluxes. The answer depends on various factors including: (1) the rates of past clearing; (2) the fate of cleared carbon (including combustion completeness, repeat fires, etc.); (3) the fate of product and slash pools; and (4) the rate of forest growth following harvest or agricultural abandonment. If the rate of clearing in historical time periods is negligible, it is clear that legacy fluxes will be small. If most of the carbon cleared during previous land uses is burned (and immediately lost to the atmosphere during those historical times), legacy fluxes will also be small. However, if a significant amount of historically cleared carbon remains in the soil to decompose or is turned into products which oxidize slowly, legacy fluxes will be high today (unless soil decomposition rates or product oxidation rates are also high). The same reasoning applies to rates of growth of secondary forests.

Ramankutty et al. (2007) explored these issues using a sensitivity analysis in the Amazon. Their "control" study used historical land-use information since 1961, assumed a constant annual fraction of $20 \%$ of cleared carbon being burned,

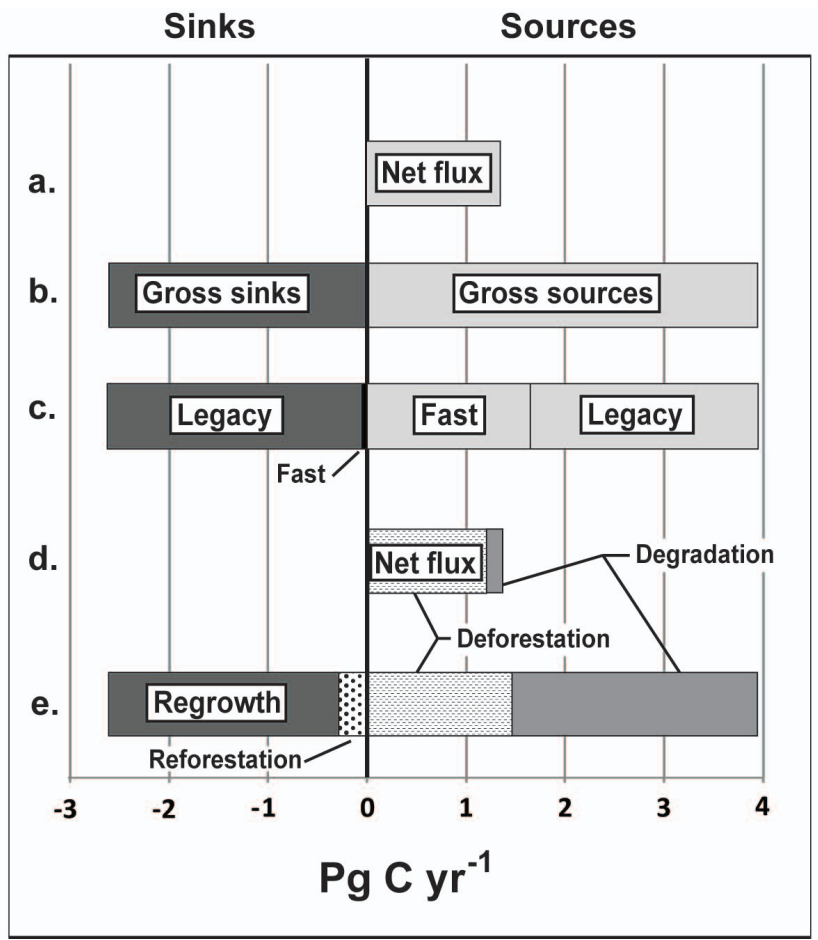

Fig. 3. Mean annual net (a) and gross (b) sources and sinks of carbon 2000-2009 attributable to LULCC (from Houghton's analysis as reported in Friedlingstein et al., 2010). Units are $\mathrm{TgC}^{-1}$. "Legacy" in 2c refers to the sinks (regrowth) and sources (decomposition) from activities carried out before 2000; "Fast" in 2c refers to sinks and sources resulting from the current year's activity. Most of the net flux (2d) is attributable to deforestation, with a smaller fraction attributable to forest degradation. The reverse is true for gross emissions 2e): degradation accounts for more of the gross emissions than deforestation. Most of the gross annual sink (2e) is attributable to regrowth (in logged forests or the fallows of shifting cultivation), with a smaller sink attributable to reforestation (an increase in forest area following abandonment of agricultural land.

$70 \%$ going to slash pools, $8 \%$ to product pools, and $2 \%$ to elemental carbon, and calculated annual actual fluxes from 1961 to 2003. When they repeated the analysis ignoring historical land use prior to 1981, they underestimated the 19901999 emissions by $13 \%$, and, while ignoring data prior to 1991 , underestimated emissions by $62 \%$. However, if the assumption of the fate of cleared carbon was altered to $70 \%$ burned annually and $20 \%$ left as slash, the underestimated emissions for ignoring pre-1981 data and pre-1991 data decreased to $4 \%$ and $21 \%$, respectively.

Globally, the contribution of instantaneous and legacy fluxes to the mean net flux 2000-2009 is shown in Fig. 3c. Instantaneous (fast) and legacy effects contribute about equally to gross emissions in this study. In contrast, gross sinks are almost entirely legacy fluxes, resulting from the uptake of carbon by secondary forests established in previous years following harvests and agricultural abandonment. 
Legacies affect the current sources and sinks of carbon not only through the accumulation of decaying pools and secondary forests, but through the current distribution of biomass density. Forests with a long history of use, for example, may have lower biomass densities than undisturbed forests, and the emissions of carbon from degraded forests, when they are deforested, will be lower than the emissions from intact forests. In this respect fluxes of carbon from LULCC are sensitive to the start times of analyses (i.e., the history of previous use) (Hurtt et al., 2011).

All the process model studies in Fig. 1 and Table 1 and the Houghton approach include legacy fluxes, while the satellite approach of DeFries et al. (2002) and Achard et al. (2004) do not. Another approach with satellite data is to calculate the "committed" flux (Fearnside, 1997; Harris et al., 2012). The committed flux counts all emissions related to a specific landuse activity; that is, both instantaneous and delayed emissions that will occur in the future, over a given time horizon. It can thus be calculated without knowing historical landuse changes. This approach may be useful in some cases, e.g., for comparing alternative land-use activities with regard to their total anticipated emissions (Fearnside, 1997). Actual and committed approaches have different intended uses, and they should not be directly compared, as demonstrated by Ramankutty et al. (2007).

\subsection{Treatment of environmental change}

Bookkeeping models use rates of growth and decay derived from the scientific literature, selecting fixed rates for different types of ecosystems. Process-based models, on the other hand, simulate these processes as a function of climate variability and trends in atmospheric $\mathrm{CO}_{2}$. Thus, a comparison of land-use effects from the two types of models will be confounded by environmental effects. Further, sinks attributable to LULCC, as calculated with bookkeeping models, will not necessarily be equivalent to sinks measured by successive forest inventories, which include environmental effects.

To separate the effects of environmental change, several process-based modeling analyses have carried out runs with and without fixed climate, $\mathrm{CO}_{2}$, and land use. For example, Pongratz et al. (2009) carried out runs with and without changing $\mathrm{CO}_{2}$ concentrations. While some model results shown in Table 1 include climate and $\mathrm{CO}_{2}$ effects on areas subject to LULCC (Piao et al., 2009; Van Minnen et al., 2009), most process-based models were run with and without LULCC, and the difference between the two runs was taken to yield the net effects of LULCC. The exercise is not perfect, because the effects of $\mathrm{CO}_{2}$ fertilization on undisturbed forests may differ, for example, from the effects on croplands or on secondary forests recovering from agricultural abandonment. Furthermore, the woody biomass of forests has a greater capacity than the herbaceous biomass of crops and grasslands to store carbon, and this capacity is reduced as forests are converted to non-forest lands. In models, the strength of this effect depends on the atmospheric $\mathrm{CO}_{2}$ concentration as well as the area of forest lost. This effect has been called the "loss of additional sink capacity" (Pongratz et al., 2009), or, when delayed emissions from past land use are included, the "net land-use amplifier effect" (Gitz and Ciais, 2003) and "replaced sinks/sources" (Strassmann et al., 2008). Estimates vary from $\sim 4 \mathrm{Pg} \mathrm{C}$ for $1850-2000$ (Pongratz et al., 2009) and 8.5 Pg C for 1950-2100 (Sitch et al., 2005), to $\sim 0.2 \mathrm{Pg} \mathrm{C} \mathrm{yr}-1$ for 1990-2000 (Strassmann et al., 2008) and $125 \mathrm{Pg} C$ for $1700-2100$ (Gitz and Ciais, 2003), including delayed emissions.

Estimates differ with respect to assumptions about climate and the atmospheric $\mathrm{CO}_{2}$ concentrations. Some estimates determine the LULCC flux under a static climate (e.g., a pre-industrial climate); others determine it under a realistically evolving climate driven by anthropogenic emissions and natural variability. Because effects are partly compensating (e.g., deforestation under increasing $\mathrm{CO}_{2}$ leads to higher emissions because $\mathrm{CO}_{2}$ fertilization has increased carbon stocks, but regrowth is also stronger under higher $\mathrm{CO}_{2}$ concentrations), a $\mathrm{CO}_{2}$ fertilization effect is not likely a major factor in differences among emission estimates (McGuire et al., 2001). Over the industrial era, the combined effects of changes in climate and atmospheric composition by one estimate have increased LULCC emissions by about $8 \%$ (Pongratz et al., 2009; Fig. 1, Table 1). Zaehle et al. (2011) included the effects of $\mathrm{N}$ deposition, and there are doubtlessly other interactions, as well, between environmental changes and management, making comparisons and attribution difficult.

Note that nearly all of the estimates in Fig. 1 exclude the fluxes of carbon driven by environmental effects on natural vegetation. Both managed and natural ecosystems may be responding similarly to environmental changes, but in this review only those lands affected by LULCC, and only those fluxes attributable to LULCC, have been included, to the extent possible.

\section{Additional LULCC processes not included in all analyses}

As discussed above (Sect. 3), variability between the estimates of flux from LULCC results, in large part, because of differences in data used to estimate deforestation rates and carbon density (see also Houghton, 2005, 2010). The variability also results from the types of land use included. All of the analyses reviewed here have included changes in the land area of forests, cropland and pastures. Additional LULCC activities, included in some but not all of the analyses in Fig. 1, are outlined in this section. 


\subsection{Forest management: Wood harvest and shifting cultivation}

Few of the global models deal with any kind of management within forest areas, even though this can lead to substantial degradation of forest carbon stocks. Selective logging in Amazonia, for example, added $15-19 \%$ to the emissions from deforestation alone (Huang and Asner, 2010). For all the tropics, Houghton (2010) estimated that harvests of wood and shifting cultivation, together, added $28 \%$ to the net emissions calculated on the basis of land-cover change alone. Globally, Shevliakova et al., 2009) estimated that harvests and shifting cultivation released an additional 32-35\% to the global net flux from land-cover change, alone (Shevliakova et al., 2009). These last two estimates of carbon loss are net losses, including both the losses of carbon from oxidation of wood products and logging debris and the uptake of carbon in secondary forests recovering from harvest. Overall, those analyses that do not include wood harvest and shifting cultivation may underestimate the net flux by $25-35 \%$.

Using Houghton's bookkeeping method over the period 2000-2009, the net emissions from forest degradation (wood harvest and shifting cultivation) accounted for about $11 \%$ of the net flux (Fig. 3d). On the other hand, they accounted for about $66 \%$ of gross emissions. Not surprisingly, the gross sources (decay of debris and wood products) and sinks (regrowth) from wood harvest and shifting cultivation are large compared to the net flux. They are also large compared to the gross emissions of carbon from deforestation alone (Baccini et al., 2012; Harris et al., 2012).

Rates of wood harvest are reported nationally by the FAO after 1960. Before that time, rates were estimated from historical narratives and national forestry statistics. Lands under shifting cultivation and changes in their areas are difficult to determine. Different approaches have been used to infer increases or decreases, including differences between FAO data sets (Houghton and Hackler, 2006) and changes in population density. Hurtt et al. (2011), in a harmonization of land-use data for Earth System models, describe the sensitivity of flux estimates to alternative assumptions concerning the distribution and magnitude of wood harvest and shifting cultivation. Different assumptions led to emissions estimates that, for wood harvest, varied by as much as $100 \mathrm{Pg} \mathrm{C}$ over the period 1500 to 2100 , and, for shifting cultivation, by as much as $50 \mathrm{Pg} \mathrm{C}$.

\subsection{Agricultural management}

The changes in soil organic carbon (SOC) that result when native lands are converted to croplands are included in most analyses, but the changes in SOC that result from cropland management, including cropping practices, irrigation, use of fertilizers, different types of tillage, changes in crop density, and changes in crop varieties, are not generally included in global LULCC model analyses. Studies have ad- dressed the potential for management to sequester carbon, but fewer studies have tried to estimate past or current carbon sinks. One analysis for the US suggests a current sink of $0.015 \mathrm{PgC} \mathrm{yr}^{-1}$ in croplands (Eve et al., 2002), while a recent assessment for Europe suggests a small net source or near-neutral conditions (Ciais et al., 2010; Kutsch et al., 2010). In Canada, the flux of carbon from cropland management is thought to be changing from a net source to a net sink, with a current flux near zero (Smith et al., 2000). Globally, the current flux from agricultural management is uncertain but probably not far from zero. Methane and nitrous oxide are the predominant greenhouse gas emissions from agriculture.

\subsection{Fire management}

The emissions of carbon from fires associated with deforestation are included in the emissions of carbon from LULCC, but wildfires have been ignored, first, because they are not directly a result of management and, second, because, in the absence of a change in disturbance regimes, the emissions from burning are presumed to be balanced by the accumulations in ecosystems recovering from fire. Fire management affects carbon stocks, yet it has been largely ignored in global analyses of LULCC despite the fact that fire exclusion, fire suppression, and controlled burning are practiced in many parts of the world. Fire management may cause a terrestrial sink in some regions (Houghton et al., 1999; Marlon et al., 2008) and a source in others. In the US fire suppression was estimated to contribute a sink of $0.06 \mathrm{Pg} \mathrm{Cyr}^{-1}$ during the 1980s (Houghton et al., 1999). The draining and burning of peatlands in Southeast Asia are considered below (Sect. 5.1).

\subsection{Land degradation}

Often the data used to reconstruct changes in land cover indicate that forest area declined more rapidly than cropland and pasture areas increased. For example, between 1900 and 1980 the net loss of forest area in China was more than three times greater than the net increase in agricultural areas (Houghton and Hackler, 2003). Assuming the data are accurate, the loss may have resulted from unsustainable harvests, from deliberate removal of forest cover (for protection from tigers or bandits), and/or from the deleterious effects of long-term intensive agriculture on soil fertility. In the latter case, forests may be cleared to replace worn out agricultural lands, but the abandoned agricultural lands do not return to forest. Whatever the cause, the excess loss of forests suggests that activities not generally reported are responsible for additional emissions of carbon - between 0.1 and $0.3 \mathrm{Pg} \mathrm{C} \mathrm{yr}^{-1}$ are estimated to have been lost in this example from China (Houghton and Hackler, 2003). The area in degraded lands is rarely enumerated (Oldeman, 1994), yet the carbon stocks are generally lower than the lands they replace. Associated emissions are very uncertain. 


\section{Additional LULCC processes not included in any analyses}

The four processes described below are not included in any of the global estimates of LULCC. Some of them will increase estimates of net carbon emissions; others are likely to decrease estimates; and some are uncertain as to their net effect.

\subsection{Peatlands, wetlands, mangroves}

Peatlands occur on all continents in the tropics, but the largest tropical peatlands and those that have received most attention from a carbon perspective are those in Southeast Asia, particularly Indonesia. Here peatlands are covered with forests that are often called peat swamp forests. Peatlands cover only a small fraction of the Earth's surface but store large amounts of carbon; estimates start at $42 \mathrm{Pg} \mathrm{C}$ for Southeast Asian peatlands compared to $70 \mathrm{Pg} \mathrm{C}$ for Amazon aboveground biomass (Hooijer et al., 2010). Peatlands accumulate carbon because decomposition rates in waterlogged soils are lower than the rates of input from vegetation growth. While undisturbed peatlands are a small carbon sink, drainage of these peatlands for agriculture and forestry often results in rapid emissions due to an increased rate of decomposition and/or an increased vulnerability to fire. In Borneo, peat swamp forests were lost to oil palm plantations at a rate of about $2.2 \% \mathrm{yr}^{-1}$ between 2002 and 2005 , higher than the loss rates for other types of forest in the region (Langner et al., 2007).

Fire emissions during the 1997-1998 El Niño in Indonesia were first estimated to be between 13 and $40 \%$ of global fossil fuel emissions because of the large quantities of peat soils burned (Page et al., 2002). More recent studies (Duncan et al., 2003; van der Werf et al., 2008) confirmed the significant contribution of peatlands to the global carbon cycle, but indicated that emissions were probably close to the lower estimate of Page et al. (2002). Fire emissions from the burning of peatlands are generally lower than during the 1997-1998 El Niño when the region experienced a long and intense dry season, but on average they are still comparable to fossil fuel emissions in the region (van der Werf et al., 2008).

Emissions of carbon from oxidation of peatlands as a result of drainage are not as well studied, yet may be more important. Quantifying these fluxes requires extensive fieldwork to monitor annual changes in peat extent, although new LIDAR-based estimates may provide estimates of the loss rates of peatlands when focused on a longer timeframe or on large burns (Ballhorn et al., 2009). The most extensive estimate so far is probably by Hooijer et al. (2010) who estimated annual emissions of between 97 and $233 \mathrm{Tg} \mathrm{C} \mathrm{yr}^{-1}$ for all of Southeast Asia, with $82 \%$ from Indonesia. These emissions vary less from year to year than fire emissions do, although oxidation rates are related to water table depth and thus to precipitation rates, which vary considerably from year to year (Wösten and Ritzema, 2001).

The combined emissions from both oxidation through drainage $\left(165 \pm 68 \mathrm{Tg} \mathrm{C} \mathrm{yr}^{-1}\right)$ and fire $\left(124 \pm 70 \mathrm{Tg} \mathrm{C} \mathrm{yr}^{-1}\right)$ in Southeast Asian peatlands are $289 \pm 138 \mathrm{Tg} \mathrm{Cyr}^{-1}$ (or $0.3 \mathrm{Pg} \mathrm{C} \mathrm{yr}^{-1}$ ) (Hooijer et al., 2010; van der Werf et al., 2008). The estimate is likely a global underestimate because other areas besides Southeast Asia may also be exploiting peatlands (Lähteenoja et al., 2009). For example, a recent study estimated that deforestation of mangroves released 0.02 to $0.12 \mathrm{PgC} \mathrm{yr}^{-1}$ (Donato et al., 2011). The high releases resulted from the carbon-rich soils, which range from 0.5 to more than $3 \mathrm{~m}$ in depth. The carbon emissions from these and other wetlands have not been included in global estimates of emissions from land-cover change.

\subsection{Human settlements and infrastructure}

Urban ecosystems account for a small area, $<0.5 \%$ (Schneider et al., 2009) to $2.4 \%$ (Potere and Schneider, 2007) of the land surface, compared to $10 \%$ in croplands, but exurban areas were nearly 15 times greater than urban areas in the US (Brown et al. 2005). Much of the deforestation in China is for residential, industrial, and commercial use rather than for agriculture (Liu et al., 2005). Highways, mining, and hydropower also add to the areas modified intensively by human activity. Despite these "uses" of land, the LULCC data sets used for the global analyses do not include urban or industrial land-use categories. The magnitude of net $\mathrm{C}$ emissions from the expansion of settled lands depends on the carbon content of the land converted (forests, grasslands), and the amount of urban vegetation established (e.g., through planting trees, irrigating desert areas).

\subsection{Erosion/redeposition}

Reviews have consistently shown that $25-30 \%$ of the soil organic carbon in the top meter is lost with cultivation (Post and Kwon, 2000; Guo and Gifford, 2002; Murty et al., 2002). This loss is generally assumed to have been released to the atmosphere. However, some of it may have been moved laterally to a different location (erosion), perhaps buried in an anoxic environment, and thereby sequestered. Comparison of erosion rates with the amount of organic carbon in freshwater sediments suggests that some of the carbon lost through erosion accumulates in riverbeds, lakes, and reservoirs (Stallard, 1998; Smith et al., 2001; Berhe et al., 2007). Recent estimates suggest that as much as $0.6 \mathrm{Pg} \mathrm{C}$ may be buried this way (Tranvik et al., 2009; Aufdenkampe et al., 2011). To the extent that soil carbon is not released to the atmosphere, but moves laterally, the emissions calculated from conversion to cultivated land (Fig. 1, Table 1) may be overestimated. On the other hand, if this flux is part of a steady-state flux, where annual inputs from crop production balance this erosional loss 


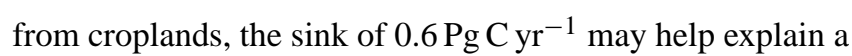
portion of the residual terrestrial sink.

\subsection{Woody encroachment}

The expansion of trees and woody shrubs into herbaceous lands is increasing carbon storage on land in many regions. Scaling it up to a global estimate is problematical, however (Scholes and Archer, 1997; Archer et al., 2001), in part because the areal extent of woody encroachment is unknown and difficult to measure (e.g., Asner et al., 2003). Also, the increase in carbon density of vegetation observed with woody encroachment is in some cases offset by losses of soil carbon (Jackson et al., 2002). In other cases the soils, too, gain carbon (e.g., Hibbard et al., 2001) or show no discernable change (Smith and Johnson, 2003). Finally, woody encroachment may be offset by its reverse process, woody elimination, an example of which is the fire-induced spread of cheatgrass (Bromus tectorum) into the native woody shrublands of the Great Basin in the western US (Bradley et al., 2006). The net effect of woody encroachment and woody elimination on carbon emissions is uncertain. Its attribution is also uncertain. Woody encroachment may be an unintended effect of management (grazing, fire suppression), or it may be a response to the indirect or natural effects of environmental change.

\section{Conclusions}

\subsection{Uncertainties}

Few studies have assessed the inherent uncertainty in estimating LULCC emissions (Houghton, 2005; Ramankutty et al., 2007). The contributions of different factors to the uncertainty of flux estimates are summarized in Table 2. For example, a sensitivity analysis by Houghton (2005) found that different estimates of vegetation biomass density reported for tropical forests in the literature yielded estimates of flux that differed by $\sim 30 \%$ or $\pm 0.3 \mathrm{Pg} \mathrm{C} \mathrm{yr}^{-1}$ (Houghton, 2005). Differences in rates of land-cover change yield similar uncertainties ( $\pm 0.4 \mathrm{Pg} \mathrm{C} \mathrm{yr}^{-1}$ in Houghton (2005) but more likely $\pm 0.3 \mathrm{Pg} \mathrm{C} \mathrm{yr}^{-1}$ currently because FAO estimates of changes in forest area are based on a greater use of satellite data and are more consistent with independent estimates of changes in agricultural areas; HYDE and SAGE data sets).

Among the analyses reviewed in Fig. 1, the standard deviation of $\sim 0.2 \mathrm{Pg} \mathrm{Cyr}^{-1}$ does not reflect the larger uncertainty within each estimate due to uncertainties in data and differences in the LULCC activities considered. The range around the model mean is generally of the order of $\pm 0.5 \mathrm{PgC} \mathrm{yr}^{-1}$, especially since the 1970 s when there are fewer discrepancies among data sets. Variations result from the data used for LULCC and biomass density, from differences among models, and from inclusion or not of different processes (e.g., environmental effects on the estimated flux) and different forms of management. For example, the difference between using the SAGE and HYDE data sets for croplands yields a difference of $0.2 \mathrm{Pg} \mathrm{Cyr}^{-1}$ (Shevliakova et al. 2009) (Table 2). The difference from using a process-based model versus a bookkeeping model is $0.3 \mathrm{Pg} \mathrm{C} \mathrm{yr}^{-1}$ (Reick et al., 2010), although this difference is largely the result of different treatments of soil carbon's response to cultivation. The difference in accounting for effects of atmospheric $\mathrm{CO}_{2}$ concentration on areas subject to LULCC is $0.1 \mathrm{Pg} \mathrm{Cyr}^{-1}$ over the period 1920 to 1999 , and $0.2 \mathrm{Pg} \mathrm{Cyr}^{-1}$ for the 1990s (Pongratz et al., 2009).

The results of this synthesis also suggest that ignoring wood harvest may yield estimates of flux that are systematically low by $0.2-0.3 \mathrm{PgC} \mathrm{yr}^{-1}$, and that analyses ignoring the draining and burning of tropical peatlands may also be low by $\sim 0.3 \mathrm{PgC}^{-1}$. Other processes that have been largely ignored, including especially fire management, erosion and redeposition, and woody encroachment, seem to have the opposite effect, namely, reducing estimated emissions. The errors for some of these additional activities and processes are often little more than guesses, obtained from regional or national studies but never evaluated globally. The errors are larger than the errors for rates of land-cover change and carbon density, and may be larger than their respective mean fluxes. The estimates (both fluxes and errors in Table 2) are tentatively advanced here to suggest directions for future research.

Finally, two processes not included in any of the analyses (erosion/redeposition and woody encroachment) are not only highly uncertain, but perhaps not LULCC processes. They are, arguably, indirect effects of LULCC, along with land degradation. If they are not LULCC activities, the overall error for emissions of carbon from LULCC is estimated to be $\pm 0.5 \mathrm{Pg} \mathrm{C} \mathrm{yr}^{-1}$. Further, if they are not considered a part of LULCC, their fluxes, instead, account for a portion of the residual terrestrial sink.

\subsection{Future directions}

Scientists working on defining the role of terrestrial ecosystems in the global carbon cycle recognized long ago the importance of satellite data for documenting changes in forest area (Woodwell et al., 1984). Satellite data for estimating carbon density are also becoming available. Data at the colocation of land-cover change and biomass density, both at relatively high resolution, offer new opportunities for estimating terrestrial sources and sinks of carbon at greater accuracy, reducing the potential bias from interaction between the two variables. Recent analyses have begun to take advantage of this opportunity (Baccini et al., 2012; Harris et al., 2012), although not at a spatial resolution necessary for capturing LULCC. New satellites are likely to provide the types of data (both rates of land use and aboveground carbon density) essential for accurate estimates of carbon fluxes. Beyond these high-resolution satellite data, the remaining 
Table 2. Summary of the factors contributing to uncertainty in estimates of emissions from LULCC and summary of processes missing from at least some of the analyses.

\begin{tabular}{lrll}
\hline & $\begin{array}{r}\text { Decadal } \\
\text { uncertainty } \\
\left(\mathrm{Pg} \mathrm{C} \mathrm{yr}^{-1}\right)\end{array}$ & Region & Reference \\
\hline Uncertainty & & & \\
\hline Land-cover change & \pm 0.3 & Globe & Houghton et al. (2005)*; Shevliakova et al. (2009) \\
Model and method & \pm 0.2 & Globe & McGuire et al. (2001); Reick et al. (2010) \\
Biomass & \pm 0.3 & Globe & Houghton et al. (2005)* \\
CO $_{2}$ & \pm 0.1 & Globe & Pongratz et al. (2009) \\
\hline Processes included in some analyses & & & \\
\hline Forest management & $+0.3 \pm 0.2$ & Globe & Shevliakova et al. (2009); Houghton (2010) \\
Agricultural management & $0 \pm 0.1$ & Europe & Ciais et al. (2010); Kutsch et al. (2010) \\
Fire management & $-0.06 \pm 0.02$ & US & Houghton et al. (1999) \\
Land degradation & $+0.2 \pm 0.1$ & China & Houghton and Hackler (2003) \\
\hline Processes included in none of the analyses & & \\
\hline Peatland drainage \& burning & $+0.3 \pm 0.1$ & SE Asia & Hooijer et al. (2010) \\
Settled lands & $+0.1 \pm 0.2$ & Globe & Estimated \\
Erosion/redeposition & $-0.6 \pm 0.3$ & Globe & Tranvik et al. (2009); Aufdenkampe et al. (2011) \\
Woody encroachment & $-0.1 \pm 0.2$ & US & Houghton et al. (1999); Hurtt et al. (2002) \\
\hline
\end{tabular}

* Based on Table 2 in Houghton (2005), updated.

challenges include identification of the fate of cleared land, attribution of observed changes in biomass density, and full accounting for carbon (i.e., changes in belowground carbon density, downed wood, and harvested wood products). Not all of the processes listed in Table 2 will be readily captured with satellite data, but the regional importance of these processes and activities requires further study.

Finally, the most promising approach for reducing the uncertainty of the residual terrestrial sink may be through improved accuracy of the LULCC flux. The better constrained the flux of carbon from LULCC is, the better constrained is the magnitude of the net residual terrestrial sink and, thereby, the likelihood of determining the mechanisms causing it. With that knowledge it may be possible to link annual $\mathrm{CO}_{2}$ emissions with the growth rate of $\mathrm{CO}_{2}$ in the atmosphere and judge the effectiveness of, and requirements for, climate mitigation policies.

Acknowledgements. Two anonymous referees offered suggestions that improved the clarity and usefulness of this paper. Support for R. A. Houghton was provided by the Woods Hole Research Center and NASA's Terrestrial Ecology Program.

Edited by: P. Ciais

\section{References}

Achard, F., Eva, H. D., Stibig, H.-J., Mayaux, P., Gallego, J., Richards, T., and Malingreau, J.-P.: Determination of deforestation rates of the world's humid tropical forests, Science, 297, 999-1002, 2002.

Achard, F., Eva, H. D., Mayaux, P., Stibig, H.-J., and Belward, A.: Improved estimates of net carbon emissions from land cover change in the tropics for the 1990s, Global Biogeochem. Cy., 18, GB2008, doi:10.1029/2003GB002142, 2004.

Aragão, L. E. O. C., Malhi, Y., Barbier, N., Lima, A., Shimabukuro, Y., Anderson, L., and Saatchi, S.: Interactions between rainfall, deforestation and fires during recent years in the Brazilian Amazonia, Phil. T. R. Soc. B, 363, 1779-1785, doi:10.1098/rstb.2007.0026, 2008.

Archer, S., Boutton T. W., and Hibbard, K. A.: Trees in grasslands: biogeochemical consequences of woody plant expansion, in: Global biogeochemical cycles in the climate system, edited by: Schulze, E.-D., Harrison, S. P., Heimann, M., Holland, E. A., Lloyd, J., Prentice, I. C., and Schimel, D., Academic Press, San Diego, 115-1337, 2001.

Arora, V. and Boer, G. J.: Uncertainties in the 20th century carbon budget associated with land use change, Glob. Change Biol., 16, 3327-3348, doi:10.1111/j.1365-2486.2010.02202.x, 2010.

Arvidson, T., Gasch, J., and Goward, S. N.: Landsat 7's long-term acquisition plan - an innovative approach to building a global imagery archive, Remote Sens. Environ., 78, 13-26, 2001.

Asner, G. P., Archer, S., Hughes, R. F., James, R., and Wessman, C. A.: Net changes in regional woody vegetation cover and carbon storage in Texas Drylands, 1937-1999, Glob. Change Biol., 9, 316-335, 2003. 
Aufdenkampe, A. K., Mayorga, E., Raymond, P. A., Melack, J. M., Doney, S. C., Alin, S. R., Aalto, R. E., and Yoo, K.: Riverine coupling of biogeochemical cycles between land, oceans, and atmosphere, Front. Ecol. Environ., 9, 53-60, 2011.

Baccini, A., Goetz, S. J., Walker, W. S., Laporte, N. T., Sun, M., Sulla-Menashe, D., Hackler, J., Beck, P. S. A., Dubayah, R., Friedl, M. A., Samanta, S., and Houghton, R. A.: Estimated carbon dioxide emissions from tropical deforestation improved by carbon-density maps, Nat. Climate Change, 2, 182185; doi:10.1038/nclimate1354, 2012.

Ballhorn, U., Siegert, F., Mason, M., and Limin, S.: Derivation of burn scar depths and estimation of carbon emissions with LIDAR in Indonesian peatlands, P. Natl. Acad. Sci. USA, 106, 21213 21218, 2009.

Barker T., Bashmakov, I., Bernstein, L., Bogner, J. E., Bosch, P. R., Dave, R., Davidson, O. R., Fisher, B. S., Gupta, S., Halsnæs, K., Heij, G. J., Kahn Ribeiro, S., Kobayashi, S., Levine, M. D., Martino, D. L., Masera, O., Metz, B., Meyer, L. A., Nabuurs, G.J., Najam, A., Nakicenovic, N., Rogner, H.-H., Roy, J., Sathaye, J., Schock, R., Shukla, P., Sims, R. E. H., Smith, P., Tirpak, D. A., Urge-Vorsatz, D., and Zhou, D.: Technical Summary, in: Climate Change 2007: Mitigation, Contribution of Working Group III to the Fourth Assessment Report of the Intergovernmental Panel on Climate Change, edited by: Metz, B., Davidson, O. R., Bosch, P. R., Dave, R., and Meyer, L. A., Cambridge University Press, Cambridge, United Kingdom and New York, NY, USA, 2007.

Berhe, A. A., Harte, J., Harden, J. W., and Torn, M. S.: The significance of the erosion-induced terrestrial carbon sink, BioScience, 57, 337-347, 2007.

Bradley, B. A., Houghton, R. A., Mustard, J. F., and Hamburg, S. P.: Invasive grass reduces aboveground carbon stocks in shrublands of the Western US, Glob. Change Biol., 12, 1815-1822, 2006.

Broich, M., Hansen, M., Stolle, F., Potapov, P., Margono, B. A., and Adusei, B.: Remotely sensed forest cover loss shows high spatial and temporal variation across Sumatra and Kalimantan, Indonesia 2000-2008, Environ. Res. Lett., 6, 014010, doi:10.1088/1748-9326/6/1/014010, 2011a.

Broich, M., Hansen, M. C., Potapov, P., Adusei, B., Lindquist, E., and Stehman, S. V.: Time-series analysis of multi-resolution optical imagery for quantifying forest cover loss in Sumatra and Kalimantan, Indonesia, Int. J. Appl. Earth Obs., 13, 277-291, 2011b.

Brown, D. G., Johnson, K. M., Loveland, T. R., and Theobald, D. M.: Rural land-use trends in the conterminous United States, 1950-2000, Ecol. Appl., 15, 1851-1863, 2005.

Caccetta, P. A., Furby, S. L., O'Connell, J., Wallace, J. F., and Wu, $\mathrm{X}$.: Continental monitoring: 34 years of land cover change using Landsat imagery, In 32nd International Symposium on Remote Sensing of Environment, 25-29 June 2007, San José, Costa Rica, 2007.

Canadell, J. G., Le Quéré, C., Raupach, M. R., Field, C. B., Buitenhuis, E. T., Ciais, P., Conway, T. J., Gillett, N. P., Houghton, R. A., and Marland, G.: Contributions to accelerating atmospheric $\mathrm{CO}_{2}$ growth from economic activity, carbon intensity, and efficiency of natural sinks, P. Natl. Acad. Sci. USA, 104, 1886618870, 2007.

Ciais, P., Wattenbach, M., Vuichard, N., Smith, P., Piao, S. L., Don, A., Luyssaert, S., Janssens, I. A., Bondeau, A., Dechow, R., Leip, A., Smith, P. C., Beer, C., van der Werf, G. R., Gervois, S.,
Van Oost, K., Tomelleri, E., Freibauer, A., Schulze, E.-D., and CARBOEUROPE SYNTHESIS TEAM: The European carbon balance, Part 2: croplands, Glob. Change Biol., 16, 1409-1428, doi:10.1111/j.1365-2486.2009.02055.x, 2010.

DeFries, R. S., Houghton, R. A., Hansen, M. C., Field, C. B., Skole, D., and Townshend, J.: Carbon emissions from tropical deforestation and regrowth based on satellite observations for the 1980s and 90s, P. Natl. Acad. Sci. USA, 99, 14256-14261, 2002.

DeFries, R. S., Morton, D. C., van der Werf, G. R., Giglio, L., Collatz, G. J., Randerson, J. T., Houghton, R. A., Kasibhatla, P. K., and Shimabukuro, Y.: Fire-related carbon emissions from land use transitions in southern Amazonia, Geophys. Res. Lett., 35, L22705, doi:10.1029/2008GL035689, 2008.

Denman, K. L., Brasseur, G., Chidthaisong, A., Ciais, P., Cox, P. M., Dickinson, R. E., Hauglustaine, D., Heinze, C., Holland, E., Jacob, D., Lohmann, U., Ramachandran, S., da Silva Dias, P. L., Wofsy, S. C., and Zhang, X.: Couplings between changes in the climate system and biogeochemistry. In: Climate Change 2007: The Physical Science Basis, Contribution of Working Group I to the Fourth Assessment Report of the Intergovernmental Panel on Climate Change, edited by: Solomon, S., Qin, D., Manning, M., Chen, Z., Marquis, M., Averyt, K. B., Tignor, M., and Miller, H. L., Cambridge University Press, Cambridge, United Kingdom and New York, NY, USA, 2007.

Donato, D. C., Kauffman, J. B., Murdiyarso, D., Kurnianto, S., Stidham, M., and Kanninen, M.: Mangroves among the most carbon-rich forests in the tropics, Nat. Geosci., 4, 293-297, doi:10.1038/ngeo1123, 2011.

Duncan, B. N., Bey, I., Chin, M., Mickley, L. J., Fairlie, T. D., Martin, R. V., and Matsueda, H.: Indonesian wild?res of 1997: Impact on tropospheric chemistry, J. Geophys. Res.-Atmos., 108, 4458, doi:10.1029/2002JD003195, 2003.

Eve, M. D., Sperow, M., Paustian, K., and Follett, R. F.: Nationalscale estimation of changes in soil carbon stocks on agricultural lands, Environ. Pollut., 116, 431-438, 2002.

FAO: Global Forest Resources Assessment 2000, Main report, FAO Forestry Paper 140, Rome, 2001.

FAO: Global Forest Resources Assessment 2005, FAO Forestry Paper 147, Rome, 2006.

FAO: Global Forest Resources Assessment 2010, FAO Forestry paper 163, Rome, 2010.

FAOSTAT: http://faostat.fao.org/site/377/default.aspx\#ancor (11/09), 2009.

FAO \& JRC: Global forest land-use change 1990-2005, edited by: Lindquist, E. J., D’Annunzio, R., Gerrand, A., MacDicken, K., Achard, F., Beuchle, R., Brink, A., Eva, H. D., Mayaux, P., SanMiguel-Ayanz, J., and Stibig, H.-J., FAO Forestry Paper No. 169, Food and Agriculture Organization of the United Nations and European Commission Joint Research Centre, Rome, FAO, 2012.

Fearnside, P. M.: Greenhouse gases from deforestation in Brazilian Amazonia: net committed emissions, Climatic Change, 35, 321360, 1997.

Friedlingstein, P., Cox, P., Betts, R., Bopp, L., von Bloh, W., Brovkin, V., Cadule, P., Doney, S., Eby, M., Fung, I., Bala, G., John, J., Jones, C., Joos, F., Kato, T., Kawamiya, M., Knorr, W., Lindsay, K., Matthews, H. D., Raddatz, T., Rayner, P., Reick, C., Roeckner, E., Schnitzler, K.-G., Schnur, R., Strassmann, K., Weaver, A. J., Yoshikawa, C., and Zeng, N.: Climatecarbon cycle feedback analysis: results from the $\mathrm{c} 4 \mathrm{mip}$ model 
intercomparison, J. Climate, 19, 3337-3353, 2006.

Friedlingstein, P., Houghton, R. A., Marland, G., Hackler, J., Boden, T. A., Conway, T. J., Canadell, J. G., Raupach, M. R., Ciais, P., and Le Quéré, C.: Update on $\mathrm{CO}_{2}$ emissions, Nat. Geosci., 3, 811-812, 2010.

Galford, G. L., Mustard, J. F., Melillo, J., Gendrin, A., Cerri, C. C., and Cerri, C. E. P.: Wavelet analysis of MODIS time series to detect expansion and intensification of row-crop agriculture in Brazil, Remote Sens. Environ., 112, 576-587, 2008.

Galford, G. L., Melillo, J. M., Kicklighter, D. W., Cronin, T. W., Cerri, C. E. P., Mustard, J. F., and Cerri, C. C.: Greenhouse gas emissions from alternative futures of deforestation and agricultural management in the southern Amazon, P. Natl. Acad. Sci. USA, 107, 19649-19654, 2010.

Giglio, L., Descloitres, J., Justice, C. O., and Kaufman, Y. J.: An enhanced contextual fire detection algorithm for MODIS, Remote. Sens. Environ., 87, 273-282, doi:10.1016/S00344257(03)00184-6, 2003.

Giglio, L., Randerson, J. T., van der Werf, G. R., Kasibhatla, P. S., Collatz, G. J., Morton, D. C., and DeFries, R. S.: Assessing variability and long-term trends in burned area by merging multiple satellite fire products, Biogeosciences, 7, 1171-1186, doi:10.5194/bg-7-1171-2010, 2010.

Gitz, V. and Ciais, P.: Amplifying effects of land-use change on future atmospheric $\mathrm{CO}_{2}$ levels, Global Biogeochem. Cy., 17, 10241029, doi:10.1029/2002GB001963, 2003.

Global Forest Survey of India: State of the Forest Report 2005, Dehradun, India: Forest Survey of India, Ministry of Environment and Forests, 2008.

Goetz, S. J., Baccini, A., Laporte, N. T., Johns, T., Walker, W., Kellndorfer, J., Houghton, R. A., and Sun, M.: Mapping and monitoring carbon stocks with satellite observations: a comparison of methods, Carbon Balance Manage., 4, 7 pp., doi:10.1186/17500680-4-2, 2009.

Government of Indonesia/World Bank: Deforestation in Indonesia: A Review of the Situation in 1999, Jakarta: Government of Indonesia/Work Bank, 2000.

Grainger, A.: Difficulties in tracking the long-term trend of tropical forest area, P. Natl. Acad. Sci. USA, 105, 818-823, 2008.

Guo, L. B. and Gifford, R. M.: Soil carbon stocks and land use change: a meta analysis, Glob. Change Biol., 8, 345-360, 2002.

Hansen, M. C., Stehman, S. V., Potapov, P. V., Loveland, T. R., Townshend, J. R. G., DeFries, R. S., Arunarwati, B., Stolle, F., Steininger, M., Carroll, M., and DiMiceli, C.: Humid tropical forest clearing from 2000 to 2005 quantified using multi-temporal and multi-resolution remotely sensed data, P. Natl. Acad. Sci. USA, 105, 9439-9444, 2008a.

Hansen, M. C., Roy, D., Lindquist, E., Justice, C. O., and Altstaat, A.: A method for integrating MODIS and Landsat data for systematic monitoring of forest cover and change in the Congo Basin, Remote Sens. Environ., 112, 2495-2513, 2008 b.

Hansen, M. C., Stehman, S. V., Potapov, P. V., Arunarwati, B., Stolle, F., and Pittman, K.: Quantifying changes in the rates of forest clearing in Indonesia from 1990 to 2005 using remotely sensed data sets, Environ. Res. Lett., 4, 034001, doi:10.1088/1748-9326/4/3/034001, 2009.

Hansen, M. C., Stehman, S. V., and Potapov, P. V.: Quantification of global gross forest cover loss, P. Natl. Acad. Sci. USA, 107, 8650-8655, 2010.
Harris, N. L., Brown, S., Hagen, S. C., Saatchi, S. S., Petrova, S., Salas, W., Hansen, M. C., Potapov, P. V., and Lotsch, A. B.: Baseline map of carbon emissions from deforestation in tropical regions, Science, 336, 1573-1576, 2012.

Hibbard, K. A., Archer, S., Schimel, D. S., and Valentine, D. W.: Biogeochemical changes accompanying woody plant encroachment in a subtropical savanna, Ecology, 82, 1999-2011, 2001.

Hooijer, A., Page, S., Canadell, J. G., Silvius, M., Kwadijk, J., Wösten, H., and Jauhiainen, J.: Current and future $\mathrm{CO}_{2}$ emissions from drained peatlands in Southeast Asia, Biogeosciences, 7, 1505-1514, doi:10.5194/bg-7-1505-2010, 2010.

Houghton, R. A.: The annual net flux of carbon to the atmosphere from changes in land use 1850-1990, Tellus B, 51, 298-313, 1999.

Houghton, R. A.: Revised estimates of the annual net flux of carbon to the atmosphere from changes in land use and land management 1850-2000, Tellus B, 55, 378-390, 2003.

Houghton, R. A.: Aboveground forest biomass and the global carbon balance, Glob. Change Biol., 11, 945-958, 2005.

Houghton, R. A.: How well do we know the flux of $\mathrm{CO}_{2}$ from land-use change? Tellus B, 62, 337-351, doi:10.1111/j.16000889.2010.00473.x, 2010.

Houghton, R. A. and Goetz, S. J.: New satellites help quantify carbon sources and sinks, Eos, 89, 417-418, 2008.

Houghton, R. A. and Hackler, J. L.: Sources and sinks of carbon from land-use change in China, Global Biogeochem. Cy., 17, 1034, doi:10.1029/2002GB001970, 2003.

Houghton, R. A. and Hackler, J. L.: Emissions of carbon from land use change in sub-Saharan Africa, Jour. Geophys. Res., 111, G02003, doi:10.1029/2005JG000076, 2006.

Houghton, R. A., Hackler, J. L., and Lawrence, K. T.: The U.S. carbon budget: contributions from land-use change, Science, 285 , 574-578, 1999.

Houghton, R. A., Butman, D., Bunn, A. G., Krankina, O. N., Schlesinger, P., and Stone, T. A.: Mapping Russian forest biomass with data from satellites and forest inventories, Environ. Res. Lett, 2, 045032, doi:10.1088/1748-9326/2/4/045032, 2007.

Huang, M. and Asner, G. P.: Long-term carbon loss and recovery following selective logging in Amazon forests, Global Biogeochem. Cy., 24, GB3028, doi:10.1029/2009GB003727, 2010.

Hurtt, G. C., Pacala, S. W., Moorcroft, P. R., Caspersen, J., Shevliakova, E., Houghton, R. A., and Moore, B.: Projecting the future of the U.S. carbon sink, P. Natl. Acad. Sci. USA, 99, 1389-1394, 2002.

Hurtt G. C., Frolking, S., Fearon, M. G., Moore, B., Shevliakova, E., Malyshev, S., Pacala, S. W. and Houghton, R. A.: The underpinnings of land-use history: three centuries of global gridded landuse transitions, wood harvest activity, and resulting secondary lands, Glob. Change Biol., 12, 1-22, 2006.

Hurtt, G. C., Chini, L. P., Frolking, S., Betts, R. A., Feddema, J., Fischer, G., Fisk, J. P., Hibbard, K., Houghton, R. A., Janetos, A., Jones, C. D., Kindermann, G., Kinoshita, T., Klein Goldewijk, K., Riahi, K., Shevliakova, E., Smith, S., Stehfest, E., Thomson, A., Thornton, P., van Vuuren, D. P., and Wang, Y. P.: Harmonization of land-use scenarios for the period 1500-2100: 600 years of global gridded annual land-use transitions, wood harvest, and resulting secondary lands, Climatic Change, 109, 117161, doi:10.1007/s10584-011-0153-2, 2011. 
Instituto Nacional de Pesquisas Espaciais (INPE): Deforestation estimates in the Brazilian Amazon, INPE, São José dos Campos, http://www.obt.inpe.br/prodes/, 2010.

Jackson, R. B., Banner, J. L., Jobbágy, E. G., Pockman, W. T., and Wall, D. H.: Ecosystem carbon loss with woody plant invasion of grasslands, Nature, 418, 623-626, 2002.

$\mathrm{Ju}, \mathrm{J}$. and Roy, D.P.: The availability of cloud-free Landsat ETM+ data over the conterminous United States and globally, Remote Sens. Environ., 112, 1196-1211, 2008.

Klein Goldewijk, K.: Estimating global land use change over the past 300 years: The HYDE Database, Glob. Biogeochem. Cy., 15, 417-433, 2001.

Klein Goldewijk, K., Beusen, A., van Drecht, G., and de Vos, M.: The HYDE 3.1 spatially explicit database of human-induced global land-use change over the past 12,000 years, Global Ecol. Biogeogr., 20, 73-86, 2011.

Kutsch, W. L., Aubinet, M., Buchmann, N., Smith, P., Osborne, B.,Eugster, W., Wattenbach, M., Schrumpf, M., Schulze, E.-D., Tomelleri, E., Ceschia, E., Bernhofer, C., Béziat, P., Carrarai, A., Di Tommasi, P., Grünwald, T., Jones, M., Magliulo, V., Marloie, O., Moureaux, C., Olioso, A., Sanz, M. J., Saunders, M., Søgaard, H., and Ziegler, W.: The net biome production of full crop rotations in Europe, Agr. Ecosyst. Environ., 139, 336-345, 2010.

Lähteenoja, O., Ruokolainen, K., Schulman, L., and Oinonen, M.: Amazonian peatlands: an ignored $\mathrm{C}$ sink and potential source, Glob. Change Biol., 15, 2311-232, 2009.

Langner, A., Miettinen, J., and Siegert, F.: Land cover change 20022005 in Borneo and the role of fire derived from MODIS imagery, Glob. Change Biol., 13, 2329-2340, doi:10.1111/j.13652486.2007.01442.x, 2007.

Le Quéré, C., Raupach, M. R., Canadell, J. G., Marland, G., Bopp, L., Ciais, P., Conway, T. J., Doney, S. C., Feely, R. A., Foster, P., Friedlingstein, P., Gurney, K., Houghton, R. A., House, J. I., Huntingford, C., Levy, P. E., Lomas, M. R., Majkut, J., Metzl, N., Ometto, J. P., Peters, G. P., Prentice, I. C., Randerson, J. T., Running, S. W., Sarmiento, J. L., Schuster, U., Sitch, S., Takahashi, T., Viovy, N., van der Werf, G. R., and Woodward, F. I.: Trends in the sources and sinks of carbon dioxide, Nature GeoScience, 2, 831-836, 2009.

Lewis, S. L., Lopez-Gonalez, G., Sonké, B., Affum-Baffo, K., and Baker, T. R.: Increasing carbon storage in intact African tropical forests, Nature, 477, 1003-1006, 2009.

Liu, J., Liu, M., Tian, H., Zhuang, D., Zhang, Z., Zhang, W., Tang, X., and Deng, X.: Spatial and temporal patterns of China's cropland during 1990-2000: an analysis based on Landsat TM data, Remote Sens. Environ., 98, 442-456, 2005.

Marlon, J. R., Bartlein, P. J., Carcaillet, C., Gavin, D. G., Harrison, S. P., Higuera, P. E., Joos, F., Power, M. J., and Prentice, I. C.: Climate and human influences on global biomass burning over the past two millennia, Nat. Geosci., 1, 697-701, 2008.

McGuire, A. D., Sitch, S., Clein, J. S., Dargaville, R., Esser, G., Foley, J., Heimann, M., Joos, F., Kaplan, J., Kicklighter, D. W., Meier, R. A., Melillo, J. M., Moore III, B., Prentice, I. C., Ramankutty, N., Reichenau, T., Schloss, A., Tian, H., Williams, L. J., and Wittenberg, U.: Carbon balance of the terrestrial biosphere in the twentieth century: Analyses of $\mathrm{CO}_{2}$, climate and land use effects with four process-based ecosystem models, Global Biogeochem. Cy., 15, 183-206, 2001.
Morton, D. C., DeFries, R. S., Shimabukuro, Y. E., Anderson, L. O., Arai, E., del Bon Espirito-Santo, F., Freitas, R., and Morisette, J.: Cropland expansion changes deforestation dynamics in the southern Brazilian Amazon, P. Natl. Acad. Sci. USA, 103, 14637-14641, 2006.

Morton, D. C., DeFries, R. S., Randerson, J. T., Giglio, L., Schroeder, W., and van der Werf, G. R.: Agricultural intensification increases deforestation fire activity in Amazonia, Glob. Change Biol., 14, 2262-2276, 2008.

Murty, D., Kirschbaum, M. F., McMurtrie, R. E., and McGilvray, H.: Does conversion of forest to agricultural land change soil carbon and nitrogen? A review of the literature, Glob. Change Biol., 8, 105-123, 2002.

Oldeman, L. R.: The global extent of soil degradation, in Soil Resilience and Sustainable Land Use, edited by: Greenland, D. J. and Szaboles, I., New York, CAB International, 99-118, 1994.

Olivier, J. G. J., van Aardenne, J. A., Dentener, F., Pagliari, V., Ganzeveld, L. N., and Peters, J. A. H. W.: Recent trends in global greenhouse gas emissions: regional trends 1970-2000 and spatial distribution of key sources in 2000, Environ. Sci., 2, 81-99, doi:10.1080/15693430500400345, 2005.

Page, S. E., Siegert, F., Rieley, J. O., Boehm, H.-D. V., Jaya, A., and Limin, S.: The amount of carbon released from peat and forest fires in Indonesia during 1997, Nature, 420, 61-65, 2002.

Pan, Y., Birdsey, R. A., Fang, J., Houghton, R., Kauppi, P. E., Kurz, W. A., Phillips, O. L., Shvidenko, A., Lewis, S. L., Canadell, J. G., Ciais, P., Jackson, R. B., Pacala, S. W., McGuire, A. D., Piao, S., Rautiainen, A., Sitch, S., and Hayes, D.: A large and persistent carbon sink in the world's forests, Science, 333, 988-993, 2011.

Phillips, O. L., Lewis, S. L., Baker, T. R., Chao, K.-J., and Higuchi, N.: The changing Amazon forest, Philos. T. Roy. Soc. B, 363, 1819-1828, 2008.

Piao, S., Ciais, P., Friedlingstein, P., de Noblet-Ducoudré, N., Cadule, P., Viovy, N., and Wang, T.: Spatiotemporal patterns of terrestrial carbon cycle during the 20th century, Global Biogeochem. Cy., 23, GB4026, doi:10.1029/2008GB003339, 2009.

Pitman, A. J., de Noblet-Ducoudré, N., Cruz, F. T., Davin, E. L., Bonan, G. B., Brovkin, V., Claussen, M., Delire, C., Ganzeveld, L., Gayler, V., van den Hurk, B. J. J. M., Lawrence, P. J., van der Molen, M. K., Müller, C., Reick, C. H., Seneviratne, S. I., Strengers, B. J., and Voldoire, A.: Uncertainties in climate responses to past land cover change: First results from the LUCID intercomparison study, Geophys. Res. Lett., 36, L14814, doi:10.1029/2009GL039076, 2009.

Pongratz, J., Reick, C., Raddatz, T., and Claussen, M.: A reconstruction of global agricultural areas and land cover for the last millennium, Global Biogeochem. Cy., 22, GB3018, doi:10.1029/2007GB003153, 2008.

Pongratz, J., Reick, C. H., Raddatz, T., and Claussen, M.: Effects of anthropogenic land cover change in the carbon cycle of the last millennium, Global Biogeochem. Cy., 23, GB4001, doi:10.1029/2009GB003488, 2009.

Pongratz, J., Reick, C. H., Raddatz, T., and Claussen, M.: Biogeophysical versus biogeochemical climate response to historical anthropogenic land cover change, Geophys. Res. Lett., 37, L08702, doi:10.1029/2010GL043010, 2010.

Post, W. M. and Kwon, K. C.: Soil carbon sequestration and landuse change: processes and potential, Glob. Change Biol., 6, $317-$ 327,2000 . 
Potere, D. and Schneider, A.: A critical look at representations of urban areas in global maps, GeoJournal, 69, 55-80, 2007.

Ramankutty, N., and Foley, J. A.: Estimating historical changes in global land cover: Croplands from 1700 to 1992, Glob. Biogeochem. Cy., 13, 997-1027, 1999.

Ramankutty, N., Gibbs, H. K., Achard, F., DeFries, R., Foley, J. A., and Houghton, R. A.: Challenges to estimating carbon emissions from tropical deforestation, Glob. Change Biol., 13, 51-66, 2007.

Reick, C., Raddatz, T., Pongratz, J., and Claussen, M.: Contribution of anthropogenic land cover change emissions to pre-industrial atmospheric $\mathrm{CO}_{2}$, Tellus B, 62, 329-336, doi:10.1111/j.16000889.2010.00479.x, 2010.

Richter, D. de B. and Houghton, R. A.: Gross $\mathrm{CO}_{2}$ fluxes from landuse change: Implications for reducing global emissions and increasing sinks, Carbon Manage., 2, 41-47, 2011.

Rosenqvist, A., Shimada, M., Ito, N., and Watanabe, M.: ALOS PALSAR: A pathfinder mission for global-scale monitoring of the environment, IEEE T. Geosci. Remote, 45, 3307-3316, 2007.

Saatchi, S. S., Houghton, R. A., dos Santos Alvala, R. C., Soares, J. V., and Yu, Y.: Distribution of aboveground live biomass in the Amazon basin, Glob. Change Biol., 13, 816-837, 2007.

Saatchi, S. S., Harris, N. L., Brown, S., Lefsky, M., Mitchard, E. T. A., Salas, W., Zutta, B. R., Buermann, W., Lewis, S. L., Hagen, S., Petrova, S., White, L., Silman, M., and Morel, A.: Benchmark map of forest carbon stocks in tropical regions across three continents, P. Natl. Acad. Sci. USA, 108, 9899-9904, 2011.

Schneider, A., Friedl, M. A., and Potere, D.: A new map of global urban extent from MODIS satellite data, Environ. Res. Lett., 4, 044003, doi:1088/1748-9326/4/4/044003, 2009.

Scholes, R. J. and Archer, S. R.: Tree-grass interactions in savannas, Annu. Rev. Ecol. Syst., 28, 517-544, 1997.

Shevliakova, E., Pacala, S., Malyshev, S., Hurtt, G., Milly, P. C. D., Casperseon, J., Sentman, L., Fisk, J., Wirth, C., and Crevoisier, C.: Carbon cycling under 300 years of land use change: Importance of the secondary vegetation sink, Global Biogeochem. Cy., 23, 1-16, 2009.

Sitch, S., Brovkin, V., von Bloh, W., van Vuuren, D., Eickhout, B., and Ganopolski, A.: Impacts of future land cover changes on atmospheric $\mathrm{CO}_{2}$ and climate, Global Biogeochem. Cy., 19, GB2013, doi:10.1029/2004GB002311, 2005.

Smith, D. L. and Johnson, L. C.: Expansion of Juniperus virginiana L. in the Great Plains: changes in soil organic carbon dynamics, Global Biogeochem. Cy., 17, 1062, doi:10.1029/2002GB001990, 2003.

Smith, S. V., Renwick, W. H., Buddemeier, R. W., and Crossland, C. J.: Budgets of soil erosion and deposition for sediments and sedimentary organic carbon across the conterminous United States, Global Biogeochem. Cy., 15, 697-707, 2001.

Smith, W. N., Desjardins, R. L., and Pattey, E.: The net flux of carbon from agricultural soils in Canada 1970-2010, Glob. Change Biol., 6, 557-568, 2000.

Stallard, R. F.: Terrestrial sedimentation and the carbon cycle: Coupling weathering and erosion to carbon burial, Global Biogeochem. Cy., 12, 231-257, 1998.
Steininger, M. K., Godoy, F., and Harper, G.: Effects of systematic sampling on satellite estimates of deforestation rates, Environ. Res. Lett., 4, 034015, doi:10.1088/1748-9326/4/3/034015, 2009.

Stocker, B. D., Strassmann, K., and Joos, F.: Sensitivity of Holocene atmospheric $\mathrm{CO}_{2}$ and the modern carbon budget to early human land use: analyses with a process-based model, Biogeosciences, 8, 69-88, doi:10.5194/bg-8-69-2011, 2011.

Strassmann, K. M., Joos, F., and Fischer, G.: Simulating effects of land use changes on carbon fluxes: past contributions to atmospheric $\mathrm{CO}_{2}$ increases and future commitments due to losses of terrestrial sink capacity, Tellus B, 60, 583-603, 2008.

Tranvik, L. J., Downing, J. A., Cotner, J. B., Loiselle, S. A., Striegl, R. G., Ballatore, T. J., Dillon, P., Finlay, K., Fortino, K., Knoll, L. B., Kortelainen, P. L., Kutser, T., Larsen, S., Laurion, I., Leech, D. M., McCallister, S. L., McKnight, D. M., Melack, J. M., Overholt, E., Porter, J. A., Prairie, Y., Renwick, W. H., Roland, R., Sherman, B. S., Schindler, D. W., Sobek, S., Tremblay, A., Vanni, M. J., Verschoor, A. M., von Wachenfeldt, E., and Weyhenmeye, G. A.: Lakes and reservoirs as regulators of carbon cycling and climate, Limnol. Oceanogr., 54, 2298-2314, 2009.

Treuhaft, R. N., Chapman, B. D., dos Santos, J. R., Gonçalves, F. G., Dutra, L. V., Graça, P. M. L. A., and Drake, J. B.: Vegetation profiles in tropical forests from multibaseline interferometric synthetic aperture radar, field, and lidar measurements, J. Geophys. Res., 114, D23110, doi:10.1029/2008JD011674, 2009.

van der Werf, G. R., Dempewolf, J., Trigg, S. N., Randerson, J. T., Kasibhatla, P. S., Giglio, L., Murdiyarso, D., Peters, W., Morton, D. C., Collatz, G. J., Dolman, A. J., and DeFries, R. S.: Climate regulation of fire emissions and deforestation in equatorial Asia, P. Natl. Acad. Sci. USA, 105, 20350-20355, 2008.

van der Werf, G. R., Randerson, J. T., Giglio, L., Collatz, G. J., Mu, M., Kasibhatla, P. S., Morton, D. C., DeFries, R. S., Jin, Y., and van Leeuwen, T. T.: Global fire emissions and the contribution of deforestation, savanna, forest, agricultural, and peat fires (19972009), Atmos. Chem. Phys., 10, 11707-11735, doi:10.5194/acp10-11707-2010, 2010.

Van Minnen, J. G., Klein Goldewijk, K., Stehfest, E., Eickhout, B., van Drecht, G., and Leemans, R.: The importance of three centuries of land-use change for the global and regional terrestrial carbon cycle, Climatic Change, 97, 123-144, 2009.

Woodwell, G. M., Hobbie, J. E., Houghton, R. A., Melillo, J. M., Moore, B., Park, A., Peterson, B. J., and Shaver, G. R.: Measurement of changes in the vegetation of the earth by satellite imagery, in: The Role of Terrestrial Vegetation in the Global Carbon Cycle: Measurement by Remote Sensing, edited by: Woodwell, G. M., SCOPE 23, John Wiley and Sons, Chichester, 221-240, 1984.

Wösten, J. H. M. and Ritzema, H. P.: Land and water management options for peatland development in Sarawak, Malaysia, Int. Peat J., 11, 59-66, 2001.

Zaehle, S., Ciais, P., Friend, A. D., and Prieur, V.: Carbon benefits of anthropogenic reactive nitrogen offset by nitrous oxide emissions, Nat. Geosci., 4, 601-605, 2011. 